\title{
A sustained approach to environmental catalysis: Reutilization of chromium from wastewater
}

\author{
Bruna Silva ${ }^{\mathrm{a}}$, Isabel C. Neves ${ }^{\mathrm{b}}$, and Teresa Tavares ${ }^{\mathrm{a}}$ \\ ${ }^{\mathrm{a} C}$ Centre of Biological Engineering, University of Minho, Campus de Gualtar, Braga, Portugal; ${ }^{\mathrm{b}} \mathrm{Centro}$ de \\ Química, University of Minho, Campus de Gualtar, Braga, Portugal
}

\begin{abstract}
Wastewater pollution with heavy metals is an issue of great environmental concern. The future development of clean technologies for the treatment of wastewater loaded with heavy metals entails environment friendly and sustainable processes that may allow simultaneously the recovery of the metals and their reutilization as value-added catalysts to be used in environmental applications. This is the first review regarding the biorecovery of metals and their further reutilization as heterogeneous catalysts. In this regard, metallic residues that generally would be considered as a waste at the end of the treatment process can be reutilized and transformed into value-added catalysts to be used in environmental applications. This review is focused in two broad areas: the biorecovery of chromium by a combined biosorption system consisting of bacteria supported on zeolites and the catalytic reutilization of the metal-loaded zeolites in the oxidation of organic compounds, in both gaseous and liquid phase. After an overview describing the main subjects in the field of heavy metals recovery, biosorption, zeolites, and catalytic oxidation, in the following sections special emphasis will be given to the main results and findings regarding these clean technologies of biorecovery and reuse of metals in catalytic reactions of environmental concern.
\end{abstract}

\section{KEYWORDS}

Biosorption; catalytic reutilization; chromium; heterogeneous catalysis; oxidation reactions; zeolites

\section{Introduction}

Water is a valuable resource that is continuously exposed to numerous sources of pollution, especially in the past few decades, due to the rapid industrialization of modern society. Among the different contaminants introduced into the environment, the release of heavy metals through industrial effluents is considered to be an issue of great concern. ${ }^{[1]}$ The release of heavy metals into the aquatic environment can lead to severe health injuries due to the accumulation of these pollutants in the food chain. Their persistence in nature ${ }^{[2,3]}$ has long-term negative effects to plant and animal ecosystems. Intensive efforts to remove heavy metals from

CONTACT Bruna Silva bsilva@deb.uminho.pt $\Theta$ Centre of Biological Engineering, University of Minho, Campus de Gualtar, Braga, Portugal.

Color versions of one or more of the figures in the article can be found online at www.tandfonline.com/best.

(c) 2016 Taylor \& Francis Group, LLC 
effluents through the development of low-cost and eco-friendly technologies have overcome the typical drawbacks of traditional treatments such as high cost and generation of toxic sludge.

Several technologies have been proposed to remediate or reduce emissions of heavy metals into the environment. While some technologies lack the possibility of recovery and/or reuse of the metals, other processes that allow recovery are costly to operate. Due to growing economic and environmental constraints, efforts have been carried out to develop recovery-reuse technologies for the treatment of heavy metal pollution. ${ }^{[4,5]}$

Chromium is one of the most toxic heavy metals, being discharged into water bodies through different industries, mainly tanneries and metal finishing plants. ${ }^{[6,7]}$ Chromium exists in different oxidation states from +2 to +6 , being the +3 and +6 the most commonly observed in environment with distinct characteristics. ${ }^{[8]}$

There are several available technologies that can be used to remove heavy metal ions from aqueous solutions. Biological approaches have been suggested in the last decade, as an alternative for the classical physicochemical techniques for heavy metals removal. One of the treatment options that have seen considerable advance in recent years is biosorption, in which inexpensive biomass or biomaterials are employed to remove heavy metal ions from aqueous media. ${ }^{[3,5,9,10]}$ Recovery of the metal ions from biosorbents is possible, and the expected low cost of the sorbents renders this technology particularly interesting. Several microorganisms, such as bacteria, are found to be able to efficiently accumulate heavy metals, and they can be selective for specific metals of interest. The self-defense strategy of bacteria consists of transforming toxic compounds into less toxic, more volatile, or readily precipitating forms, through mechanisms that can include oxidation, reduction, or methylation. Several publications have shown that certain species of bacteria are able to perform the reduction of hexavalent chromium, $\mathrm{Cr}(\mathrm{VI})$, into trivalent chromium, $\mathrm{Cr}(\mathrm{III})$, which is less toxic and less mobile. ${ }^{[11-19]}$

Low-cost ion exchangers, such as zeolites, have been extensively used in the recovery of metals thanks to their peculiar ion exchange capacity and selectivity. The fact that the exchangeable ions of zeolites are relatively innocuous makes these a clean and ecological material suitable for the removal of undesirable heavy metal ions from industrial effluent water. The use of zeolites as highly valued ion exchangers for the removal of heavy metal contamination (and other pollutants) in aqueous media has been referred as a low-cost approach by many authors. ${ }^{[2,20-23]}$

Zeolites have received great interest because of their optimum performance as solid acid catalysts in refining and petrochemical processes. ${ }^{[24-26]}$ In addition, the use of zeolites as powerful catalytic supports or even catalysts for many oxidation reactions has gained particular attention ${ }^{[27-31]}$ due to their remarkable properties, such as crystalline structure, acidic-basic properties, pore geometry, and large surface areas. ${ }^{[32,33]}$ Zeolites can be modified or synthesized for use in catalysis by inclusion of metal species in their structure. The insertion of catalytically active metal species offers the possibility of operating with bifunctional (redox-acid) 
catalysts. $^{[34]}$ Although noble metal catalysts are known to have higher activity than metal oxides, some disadvantages, such as their limited availability, high cost, and tendency to poisoning, ${ }^{[35,36]}$ demand their replacement by cost-effective transition metals. $^{[37,38]}$ In the last decade, zeolites doped with transition metals (e.g., $\mathrm{Ni}, \mathrm{Cr}$, $\mathrm{Co}$, and $\mathrm{Cu}$ ) have been shown promising results in the field of heterogeneous catalysis, namely in pollution control and selective oxidation. Numerous studies have been done in order to evaluate the properties of transition metal exchanged or impregnated zeolite catalysts in gas phase oxidation of VOC. ${ }^{[39-46]}$ For liquid phase, it is documented that metals acting as catalysts in zeolites present stability problems in the oxidation reactions, which is related to possible leaching of active metal components into solution. ${ }^{[4]}$ A common approach to prevent this leaching is linking the transition metal on a solid support by coordination with organic ligands. ${ }^{[4,49]}$ The possible applications of transition metal complexes immobilized into solid supports have received large attention because of their potential use in heterogeneous catalysis in mild conditions. ${ }^{[50-52]}$

\section{Recovery of metals from wastewater using bacteria and zeolites}

Heavy metals occur naturally in soils, sedimentary deposits, and water bodies, and so there is a normal background concentration of these elements. Such metals are considered to be pollutants when their concentrations increase to such an extent that they present a risk to living organisms. ${ }^{[53]}$ The main anthropogenic sources of heavy metals are several industrial activities including mining, metallurgical, electroplating, and metal finishing. The discharge of industrial effluents containing heavy metals is extremely undesirable, as they can present acute toxicity to both lower and higher organisms. The nonbiodegradability of heavy metals results in their accumulation in environment and living tissues, thus causing several health effects in humans and animals, as well as potential severe ecological damages. ${ }^{[1,54]}$

Among the common heavy metals present in industrial wastewater, mercury, lead, cadmium, and chromium are at the top in terms of toxicity. ${ }^{[55]}$ In this review, special emphasis will be given to chromium due to its harmful effects to human health and environment and simultaneously to its catalytic properties in oxidation reactions of organic compounds. ${ }^{[41,42,44,45,56]}$

\subsection{Chromium chemistry, redox behavior, and toxicity}

Chromium occurs in variable oxidation states ranging from -2 to +6 , but only the +3 and +6 states are stable under commonly observed environmental conditions. ${ }^{[8,57]}$ Compounds of the trivalent oxidation state usually form chromium hydroxides in water, being mono- or polynuclear species $\left(\mathrm{CrOH}^{2-}, \mathrm{Cr}(\mathrm{OH})^{2+}, \mathrm{Cr}\right.$ $(\mathrm{OH})_{3}, \mathrm{Cr}(\mathrm{OH})^{4-}, \mathrm{Cr}_{2}(\mathrm{OH})_{2}$, or $\left.\mathrm{Cr}_{3}(\mathrm{OH})_{4}{ }^{5+}\right)$, whereas the hexavalent chromium predominantly forms chromate or dichromate anions $\left(\mathrm{CrO}_{4}{ }^{2-}\right.$ and $\mathrm{Cr}_{2} \mathrm{O}_{7}{ }^{2-}$, respectively). ${ }^{[58]}$ It is important to refer that hexavalent chromium, $\mathrm{Cr}(\mathrm{VI})$, is not present in the environment as a free cation, $\mathrm{Cr}^{6+}$, but in the form of oxyanions, 


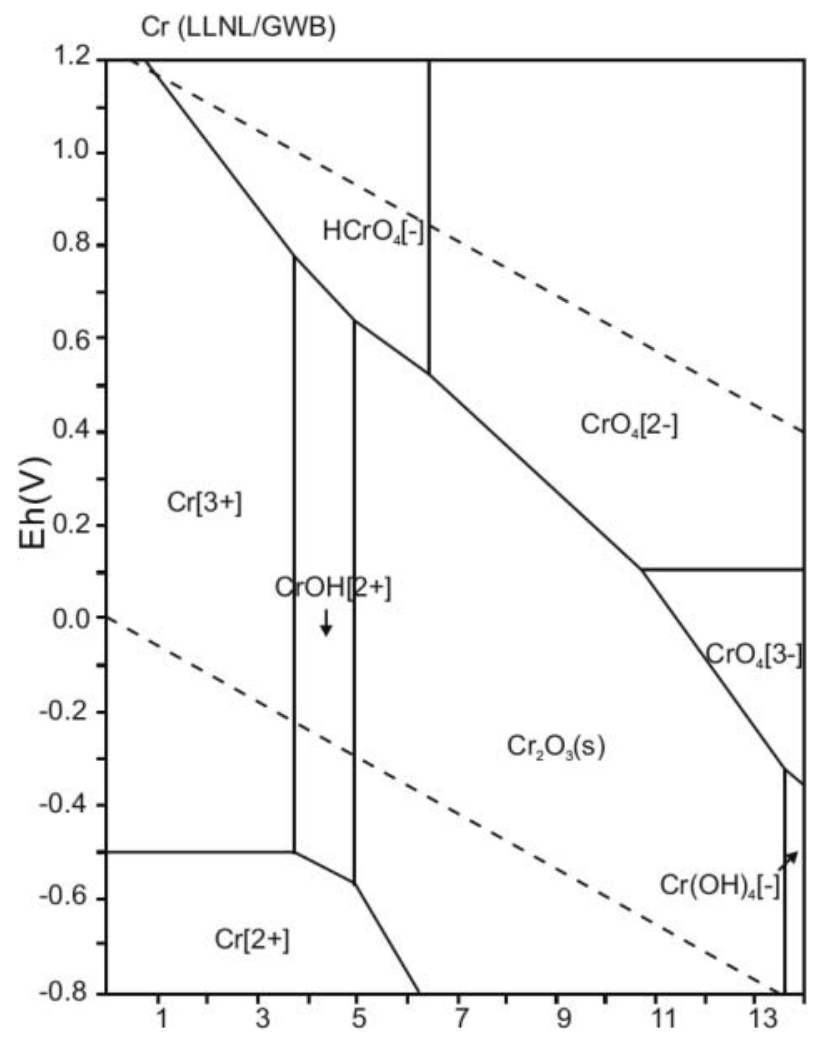

Figure 1. Eh-pH diagram of the system $\mathrm{Cr}-\mathrm{O}-\mathrm{H} . \Sigma \mathrm{Cr}=10^{-10}, 298.15 \mathrm{~K}, 105 \mathrm{~Pa}$. (Adapted from ref. ${ }^{[59]}$ )

whereas trivalent chromium, $\mathrm{Cr}(\mathrm{III})$, does exist as $\mathrm{Cr}^{3+}$. Chromium species are strongly controlled by the redox conditions of the aquatic media. The Eh-pH diagram presented in Fig. $1^{[59]}$ provides a generalized representation of the major aqueous chromium species in chemical equilibrium at different redox conditions.

$\mathrm{Cr}(\mathrm{VI})$ species predominately occur under oxidizing (high Eh) and alkaline conditions. Hexavalent chromium is a strong oxidizer and therefore exists only as soluble oxygenated species, depending on the $\mathrm{pH}$ of the aqueous environment. The most common $\mathrm{Cr}(\mathrm{VI})$ species in natural systems are chromate $\left(\mathrm{CrO}_{4}{ }^{2-}\right)$, at $\mathrm{pH}>6$, and hydrogen chromate $\left(\mathrm{HCrO}^{4-}\right)$, at the $\mathrm{pH}$ range 1-6. In its turn, trivalent chromium species are stable under reducing aqueous environments (low Eh). $\mathrm{The}^{3{ }^{3+}}$ ions are prevalent only at $\mathrm{pH}$ lower than 4 . With the increase of $\mathrm{pH}$, hydrolysis of $\mathrm{Cr}^{3+}$ yields $\mathrm{Cr}(\mathrm{OH})^{2+}$, at the $\mathrm{pH}$ range $4-5$, and $\mathrm{Cr}(\mathrm{OH})^{4-}$, at $\mathrm{pH}>13$.

In terms of redox behavior, chromium may undergo changes in oxidation state depending on the different redox conditions of the aquatic environment. The reduction of $\mathrm{Cr}(\mathrm{VI})$ to $\mathrm{Cr}(\mathrm{III})$ or the oxidation of $\mathrm{Cr}(\mathrm{III})$ to $\mathrm{Cr}(\mathrm{VI})$ requires the presence of another redox couple, that is, a reducing or oxidizing agent, respectively, which gives or accepts the necessary electrons. $\mathrm{Cr}(\mathrm{VI})$ is a strong oxidant and therefore can be reduced in the presence of reducing agents found commonly in soil, water, and atmospheric systems. The most common species of hexavalent 
chromium, $\mathrm{CrO}_{4}{ }^{2-}, \mathrm{HCrO}_{4}{ }^{-}$, and $\mathrm{Cr}_{2} \mathrm{O}_{7}{ }^{2-}$, can be quite readily reduced to $\mathrm{Cr}$ (III) species in the presence of electron donors, such as organic matter and reduced inorganic compounds, namely $\mathrm{Fe}(\mathrm{II})$ and $\mathrm{S}^{2-} \cdot{ }^{\left[{ }^{60-62]}\right.}$ Another important route of $\mathrm{Cr}(\mathrm{VI})$ reduction is mediated by microbial biomass. Several microorganisms are capable of transforming hexavalent chromium into less toxic species, trivalent chromium, thus having an important role in the reduction of the toxicity of these compounds. Microorganisms can perform the reduction of $\mathrm{Cr}(\mathrm{VI})$ by a combination of several mechanisms, namely enzymatic extracellular reduction, reduction by bacterial surfaces, and intracellular reduction and precipitation. ${ }^{[63]}$ Microorganisms capable of reducing $\mathrm{Cr}(\mathrm{VI})$ to $\mathrm{Cr}(\mathrm{III})$ include bacteria, yeasts, and fungi. ${ }^{[64]} \mathrm{A}$ number of bacterial species have been reported as capable of detoxifying $\mathrm{Cr}(\mathrm{VI})$, namely Pseudomonas, ${ }^{[6]}$ Bacillus, $^{[66]}$ Achromobacter, ${ }^{[67]}$ Arthrobacter, ${ }^{[16,18,19]}$ Escherichia, ${ }^{[68]}$ and Enterobacter. ${ }^{[69]}$

$\mathrm{Cr}(\mathrm{III})$ and $\mathrm{Cr}(\mathrm{VI})$ have contrasting physicochemical properties, as well as chemical and biochemical reactivity. $\mathrm{Cr}(\mathrm{VI})$ anions are highly mobile and can easily migrate in aquatic environments due to repulsive electrostatic interactions with soil particles that are negatively charged. In contrast, trivalent chromium species normally carry positive charges and are less mobile since they can be easily adsorbed on the soil particles. ${ }^{[70]}$ In terms of toxicity, biological intrinsic activity, and nutritional value, chromium is probably the most controversial element among the different transition metals. While $\mathrm{Cr}(\mathrm{III})$ is essential at trace levels as a nutrient in human and animal health, $\mathrm{Cr}(\mathrm{VI})$ is very toxic, with well-established carcinogenic effects in humans. ${ }^{[71,72]}$ Trivalent chromium plays an important role in insulin signaling and glucose metabolism, being also involved in the regulation of levels of glucose and low-density lipoprotein cholesterol (LDL) in blood. ${ }^{[58,73]}$ In opposition, the higher toxicity of $\mathrm{Cr}(\mathrm{VI})$ is associated with its higher solubility in aqueous media and permeability through biological membranes, which favors the interaction with proteins and nucleic acids. ${ }^{[74]}$ The exposure to hexavalent chromium may lead to several adverse effects in human health, namely allergic responses, nasal septum injury, asthma, larynx inflammation, and lung carcinoma. ${ }^{[75]}$

\subsection{Biosorption}

With increasing environmental awareness and strict regulations that specify maximum allowable concentrations of heavy metals in effluents, there is a growing need for the development of new economical, ecological, and effective methods for metals removal.

The conventional methods used for metal ions removal include chemical precipitation, ion exchange, membrane separation, ultrafiltration, electrochemical methods, and adsorption. However, these methods have some important limitations, such as low efficiency and high operational costs, especially for the treatment of large volumes of wastewater with concentration of metal ions ranging from 1 to $100 \mathrm{mg} \mathrm{L}^{-1} \cdot[3,76]$ 
In recent years, research attention has been focused on the use of biological materials capable of binding metal ions present in effluents. In this regard, the biosorption process appears as an advantageous alternative method in comparison with the others above mentioned. The biosorption is a selective, effective, and cheap method that can be applied at very low metal concentrations. In addition, the biosorption process does not generate toxic sludge, as well as offers the possibility of metal recovery and biosorbent regeneration. ${ }^{\text {[77] }}$

The term biosorption is used to express the fixation and accumulation of metals by biological materials without active uptake. ${ }^{[78]}$ Metals can be accumulated by a variety of processes dependent and independent on metabolism. Both living and dead biomass as well as cellular products, such as polysaccharides can be used for metals removal. ${ }^{[79]}$ The uptake of metals independent of biological metabolism is known as passive uptake or biosorption, whereas active uptake is metabolism dependent, involving the active transport of the metals across the cell membrane. The metal uptake by both active and passive uptake is called bioaccumulation, and both modes can be employed by living cells. On the other hand, dead cells can only employ the passive mode for metals uptake, that is, through biosorption. ${ }^{[58]}$

Metal ions bind to cells by different physicochemical mechanisms, depending on the biomass and environmental conditions. Several mechanisms are involved in the biosorption of metals, namely ion exchange, adsorption, complexation, chelation, coordination, and microprecipitation. The sequestration of the metal species by biosorbents can occur through a single mechanism or through a combination of mechanistic steps. ${ }^{[80]}$ During the biosorption process, the metal interacts with the cell wall surface that possesses several metal-binding functional groups, such as carboxyl, phosphoryl, amido, amino, imidazole, and sulfonate. ${ }^{[81,82]}$ This phenomenon of metal binding is independent of metabolism and is quite common, relatively rapid, and reversible. In this regard, biomass gathers some of the chemical characteristics of an ion exchange and some others of an activated carbon, which brings many advantages into the industrial application of biosorption. In the case of microprecipitation, this mechanism can take place both in solution and on the cell surface. For living cells, this process acts like a protection mechanism that is performed by the microorganisms that, in the presence of toxic metals, produce compounds which favor their precipitation. Nevertheless, this precipitation process can occur independently of cell metabolism, after a chemical interaction between the metal and the cell surface. ${ }^{[81]}$ In addition, living cells can accumulate metals intracellularly through a metabolism-dependent process that is also energy dependent and requires an active respiration by the cell through a specific transport system. This process of intracellular accumulation is usually slower in comparison with adsorption, although in many cases the amount of metals that are bound to cells is higher than in the case of a purely external process. ${ }^{[3]}$

A large number of biological materials have been shown the ability to bind heavy metals, namely bacteria, yeast, fungi, biological wastes, algae, and 
polysaccharide materials. ${ }^{[3]}$ Even though any type of biosorbents can be used, the biomass of microbial origin presents several benefits when applied in large-scale processes. The main advantages include their low cost, larger surface areas per unit volume, ${ }^{[83]}$ possibility of metal recovery and biosorbents regeneration, and minimization of biological and chemical sludge. ${ }^{[84]}$

Among the different bacterial species, Arthrobacter viscosus is an interesting bacterium with respect to metal binding capacity, which is related to its ability to produce considerable amounts of extracellular polysaccharides (EPS). ${ }^{[85]}$

\subsubsection{Arthrobacter viscosus}

Bacteria of the genus Arthrobacter are one of the most predominant groups in soils, sediments, and subsurface environments. Arthrobacter is a genus composed of Gram-positive, aerobic, and heterotrophic organisms. ${ }^{[86]}$ Members of the genus Arthrobacter show a life cycle characterized by cell morphological changes. During the exponential growth, the cells are rod-shaped (bacillis), while in the stationary phase the cells take a round shape (cocci).

Since Arthrobacter bacteria utilize a wide variety of organic compounds as substrate, including aromatic hydrocarbons, they are widely believed to play a significant role in the transformation of organic matter in natural environments. ${ }^{[86]}$ Westerberg et al. ${ }^{[87]}$ demonstrated the ability of a new species isolated from soil, Arthrobacter chlorophenolicus, to degrade high concentrations of 4-chlorophenol. In addition, O'Loughlin et al. ${ }^{[88]}$ studied the degradation of 2-methylpyridine, 2-ethylpyridine, and 2-hydroxypyridine by Arthrobacter sp., isolated from subsurface sediments collected from an aquifer located at an industrial site. These authors demonstrated that the bacterium was capable of utilizing these aromatic compounds as primary carbon, nitrogen, and energy sources.

Arthrobacter viscous bacterium has been reported in several studies as a good exopolysaccharide (EPS) producer. ${ }^{[85,89-91]}$ It is well known that bacterial EPS is involved in the mechanisms of biofilm formation and also play a crucial role in the biosorption of metals. ${ }^{[92]}$ Quintelas et al. ${ }^{[93]}$ developed studies in a pilot-scale bioreactor, showing the ability of a biofilm of Arthrobacter viscosus supported on GAC to remove of $\mathrm{Cr}(\mathrm{VI})$ from aqueous solutions. Arthrobacter species have been also reported as capable of binding other metal ions, such as $\mathrm{Fe}(\mathrm{III}), \mathrm{Cu}(\mathrm{II})$, and $\mathrm{Cd}(\mathrm{II})^{[94]}$ as well as $\mathrm{Mn}(\mathrm{II}), \mathrm{Ni}(\mathrm{II})$, and $\mathrm{Pb}(\mathrm{II}) .{ }^{[95]}$

\subsection{2. $\mathrm{Cr}(\mathrm{VI})$ reduction by Arthrobacter viscosus}

Several species of the genus Arthrobacter have revealed the ability to reduce Cr(VI) into its less harmful form, $\mathrm{Cr}$ (III). Lin et al. ${ }^{[96]}$ studied the chromate-resistant basalt-inhabiting Arthrobacter K-2 and K-4 and concluded that the polysaccharides present in the cell capsule played an important role in the reduction of $\mathrm{Cr}$ (VI) to $\mathrm{Cr}$ (III) and therefore in their survival ability. Other authors ${ }^{[97]}$ demonstrated that the reduction of chromium by Arthrobacter oxydans occurs in diol groups of the cell wall, through the formation of an instable intermediate, $\operatorname{Cr}(\mathrm{V})$. 

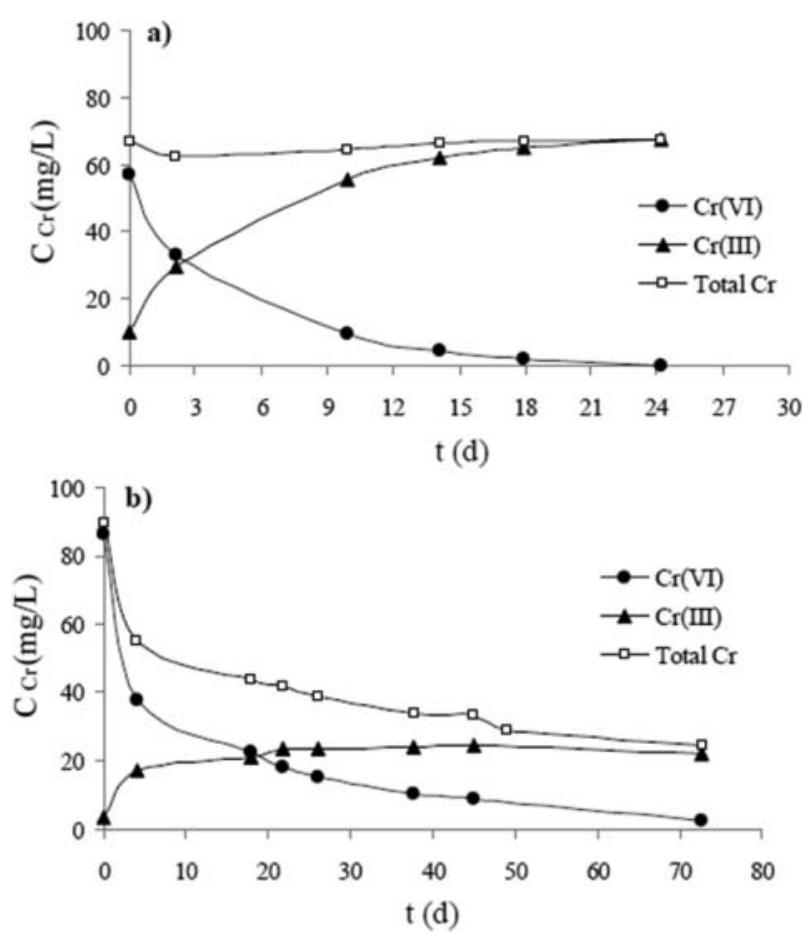

Figure 2. Concentrations of different chromium species as a function of contact time, during $\mathrm{Cr}(\mathrm{VI})$ biosorption by $A$. viscosus in suspension at $\mathrm{pH} 2$ (a) and $\mathrm{pH} 4$ (b). ${ }^{[19]}$

(c) Elsevier. Reproduced by permission of Elsevier. Permission to reuse must be obtained from the rightsholder.

Silva et al. ${ }^{[19]}$ reported the reduction of $\mathrm{Cr}(\mathrm{VI})$ to $\mathrm{Cr}(\mathrm{III})$ by living cells of Arthrobacter viscosus, during biosorption experiments at acidic conditions (Fig. 2). Figure 3 presents the XPS wide scan spectrum and the high-resolution spectrum, collected from the $\mathrm{Cr} 2 \mathrm{p}$ core region, of the Cr-laden biomass obtained after the biosorption of $\mathrm{Cr}(\mathrm{VI})$ at $\mathrm{pH}$ 4. The authors ${ }^{[19]}$ concluded that the chromium bound to the biomass surface was in the trivalent oxidation state. Numerous research studies have reached the same conclusions that chromium bound to biomass after $\mathrm{Cr}(\mathrm{VI})$ biosorption was in the trivalent state. ${ }^{[98-100]}$

Silva et al. ${ }^{[19]}$ claimed that the mechanism of chromium removal can be explained by several phenomena, such as reduction of $\mathrm{Cr}(\mathrm{VI})$, adsorption/ desorption of chromium ions, and protonation/deprotonation of the cell wall functional groups which is $\mathrm{pH}$ dependent. The findings of the authors are in agreement with the assumptions made in previous reports ${ }^{[100-102]}$ that demonstrate that the biosorption mechanism of $\mathrm{Cr}(\mathrm{VI})$ by biomaterials is not "anionic adsorption" but "adsorption-coupled reduction." In acidic solutions, $\mathrm{Cr}(\mathrm{VI})$ can easily be reduced to $\mathrm{Cr}(\mathrm{III})$ by electron-donor groups of the biomass, due to its higher redox potential value. These authors stated that the removal of $\mathrm{Cr}(\mathrm{VI})$ can occur through both direct and indirect reduction mechanisms, as represented in Fig. 4. 


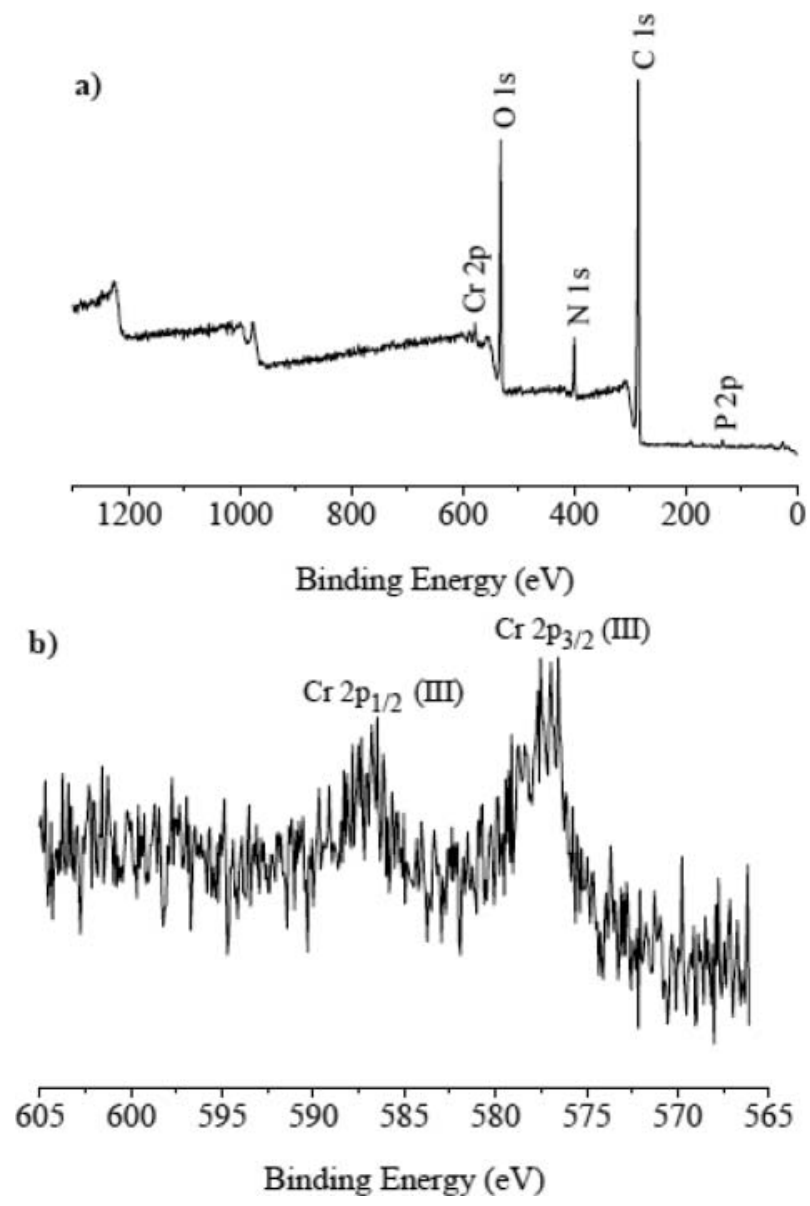

Figure 3. XPS survey scanning spectrum (a) and high-resolution $\mathrm{Cr} 2 \mathrm{p}$ spectrum (b) of chromiumloaded biomass. ${ }^{[19]}$

(c) Elsevier. Reproduced by permission of Elsevier. Permission to reuse must be obtained from the rightsholder.

Mechanism II

Mechanism I

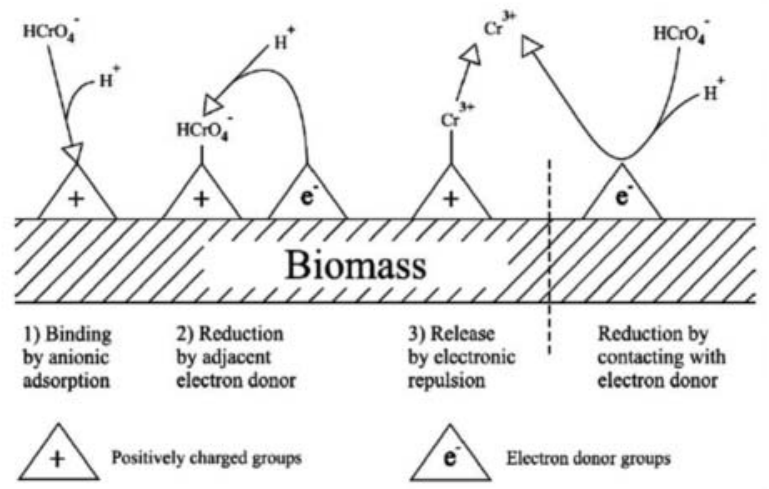

Figure 4. Mechanism for $\mathrm{Cr}(\mathrm{VI})$ removal by biomaterials. ${ }^{[101]}$

(c) Elsevier. Reproduced by permission of Elsevier. Permission to reuse must be obtained from the rightsholder. 
In mechanism I, $\mathrm{Cr}$ (III) is formed by direct reduction when $\mathrm{Cr}(\mathrm{VI})$ comes in contact with the functional groups of the biomass surface that have lower reduction potential than that of $\mathrm{Cr}(\mathrm{VI})$. The indirect reduction mechanism (mechanism II) involves three steps:

i) The anionic $\mathrm{Cr}(\mathrm{VI})$ species bind to the groups of the biomass surface that are positively charged;

ii) $\mathrm{Cr}(\mathrm{VI})$ is reduced to $\mathrm{Cr}$ (III) by adjacent electron-donors groups;

iii) The cationic Cr(III) species are released into the aqueous solution by electronic repulsion with the positively charged groups that are present on of the biomass surface, or alternatively can form complexes with adjacent groups capable of binding chromium.

Currently, this mechanism so-called adsorption-coupled reduction has been widely used to describe the biosorption of $\mathrm{Cr}(\mathrm{VI}) .{ }^{[103-107]}$

\subsection{Zeolites}

Zeolites are crystalline microporous aluminosilicates with a defined 3D structure, composed of $\mathrm{TO}_{4}$ tetrahedra $(\mathrm{T}=\mathrm{Si}, \mathrm{Al})$ with oxygen atoms connecting neighboring tetrahedra. A zeolite framework containing exclusively oxygen-sharing $\mathrm{SiO}_{4}{ }^{4-}$ tetrahedra is neutral. The $3 \mathrm{D}$ arrangement of these tetrahedral units gives place to a wide diversity of open-framework topologies, conforming channels and cavities of well-defined dimensions. When $\mathrm{Al}^{3+}$ replaces $\mathrm{Si}^{4+}$ isomorphically in the framework, this becomes negatively charged and that requires the presence of extraframework cations (inorganic and organic cations) to keep the electroneutrality of the solid. These balancing cations can readily be exchanged by other cations in solution. ${ }^{[50,108]}$ The framework structure of a zeolite is made of channels or interconnected voids, where are located the cations and water molecules. Generally, the intracrystalline water can be reversibly removed by heating, without any damage to the structure. ${ }^{[109]}$

The main application of the zeolites in industry is as cation exchangers due to their ion exchange capacity. ${ }^{[10,111]}$ The use of zeolites as anion adsorbents has been very limited so far. This is probably due to the fact that zeolites have negative surface charge which provides them with high adsorption capacities for cations, but low for anions because of electrostatic repulsions when anions approach the zeolite surface. $^{[112]}$

Likewise, the remarkable properties, zeolites have nowadays an important role in catalysis. ${ }^{[30]}$ It is known that materials with high thermal stability, resistance to humidity, high surface area, and ability to stabilize the metal particles in the porous structure are adequate for catalytic processes. The type of support has a significant influence on metal dispersion. Several important features of zeolites, such as the variety of porous structures, hydrophobicity, and possibility to control strength and distribution of acid sites, make them advantageous supports in comparison with the traditional ones. ${ }^{[113]}$ 
The catalytic activity of zeolites is related to framework structure and composition. The zeolitic acidic sites can be generated by the introduction of protons in the structure that will create the Brønsted acid site. ${ }^{[5]}$ The global activity of the Brønsted acid sites depends on several factors, such as their density in the framework, the zeolite $\mathrm{Si} / \mathrm{Al}$ ratio (which will interfere in the acid strength of the sites), and the local strain on bond angles. It was found that high-silica zeolites present much stronger Brønsted acid sites, despite their lesser availability of $\mathrm{Al} \mathrm{T}$ atoms, which lead to the development of high-silica zeolites, such as the ZSM5, which are of great importance for the petrochemical industry. ${ }^{[108]}$ Zeolites may also present Lewis acidity by loss of water of the Brønsted acid sites upon heating.

\subsubsection{Removal of metal ions by zeolites}

Water and wastewater treatment by zeolites is essentially based on their remarkable properties, such as adsorbents and ion exchangers. Ion exchange properties are mainly characterized by sieving effects, cation exchange capacity (CEC), and ion exchange selectivity. ${ }^{[110]}$ As it was discussed above, zeolites possess a net negative structural charge that is balanced by cations that occupy the channels within the structure, such as sodium, potassium, or calcium. These cations can be replaced by others in solution, due to the strong affinity of the zeolites for metal cations. ${ }^{[114}$, ${ }^{115]}$ One of the earliest applications of natural zeolites was in the purification of water containing cesium and strontium radioisotopes, during the Chernobyl disaster. ${ }^{[16]}$ Zeolites have been considered as suitable materials to be used in the treatment of industrial effluents, since their exchangeable ions $(\mathrm{Na}, \mathrm{Ca}, \mathrm{K}$, and $\mathrm{Mg}$ ) are relatively innocuous to the environment. ${ }^{[114]}$ Several factors may affect the uptake efficiency of zeolites, namely the solution $\mathrm{pH}$, temperature, relative dimensions of the hydrated dissolved species and the pores, presence of competing cations and complexing agents, initial metal concentration, and external surface activity. ${ }^{[117]}$ Other important factor affecting the removal performance of metals by zeolites is their cation exchange capacity, which is intrinsically related to the $\mathrm{Si} / \mathrm{Al}$ ratio and cation affinity. When a zeolite framework contains an equal number of aluminum and silicon atoms, each oxygen atom is linked to one aluminum and to one silicon atom and the cavities contain the maximum density of exchangeable cations. Synthetic zeolites with such a maximum cation exchange capacity are of interest as ion exchangers. Solache-Ríos ${ }^{[118]}$ reported the following sequence of CEC for synthetic zeolites: A > X, Y > ZSM5. The higher CEC of Y zeolite compared to ZSM5 zeolite allows foreseeing a better removal performance of metal cations. Several studies have reported the removal performance of heavy metal cations by natural zeolites ${ }^{[119-122]}$ as well as synthetic zeolites. ${ }^{[123-126]}$

Although zeolites have a strong affinity for metal cations, they have almost no affinity for anions, such as $\mathrm{Cr}(\mathrm{VI})$, or nonpolar organic molecules. ${ }^{[115]}$ The negative charge of the framework $\mathrm{Al}$ atoms, which are situated inside the pore structure, gives the zeolites remarkable adsorptive properties. Several authors reported zeolites to be ineffective for $\mathrm{Cr}(\mathrm{VI})$ removal, and therefore, surface pretreatments with 
cationic surfactants have been proposed, in order to enhance their removal ability. Leyva-Ramos et al. ${ }^{[127]}$ studied the removal of $\mathrm{Cr}(\mathrm{VI})$ by a natural zeolite modified with the cationic surfactant hexadecyltrimethylammonium (HDTMA) bromide, achieving uptake values between 0.21 and $5.19 \mathrm{mg}_{\mathrm{Cr}(\mathrm{VI})} \mathrm{g}_{\text {zeolite }}{ }^{-1}$, depending on the solution $\mathrm{pH}$. A similar study was performed by Yusof and Malek ${ }^{[128]}$ that investigated the removal performance of $\mathrm{Cr}(\mathrm{VI})$ by a commercial $\mathrm{NaY}$ zeolite modified with hexadecyltrimethylammonium bromide (HDTMABr). However, these authors obtained very low removal efficiencies and uptake values, between 1.35 and $1.63 \mathrm{mg}_{\mathrm{Cr}(\mathrm{VI})} \mathrm{g}_{\text {zeolite }}{ }^{-1}$, depending on the surfactant loading onto commercial Y zeolite. In alternative to surface pretreatments, zeolites can be used to efficiently remove hexavalent chromium after its previous reduction to cationic $\mathrm{Cr}$ (III) species, which can be achieved by the action of a bacterium.

Silva et al. ${ }^{[18]}$ reported that Arthrobacter viscosus bacterium supported on a $\mathrm{NaY}$ zeolite performed the reduction of $\mathrm{Cr}(\mathrm{VI})$ to $\mathrm{Cr}$ (III), and then, $\mathrm{Cr}$ (III) could be retained in the zeolite by ion exchange. In this way, the bacteria play an important role in metal loading process, since sterical restrictions and charge repulsions would not allow the fixation of negatively charge chromium species $\left(\mathrm{Cr}_{2} \mathrm{O}_{7}{ }^{2-}\right)$ by the zeolite itself. ${ }^{[1]}$ These authors showed that the zeolite by itself was not able to remove $\mathrm{Cr}(\mathrm{VI})$ due to its anionic form. However, in the presence of the bacterium, the removal efficiency was flagrantly improved. An important operational parameter for the practical use of biosorption systems is the solution $\mathrm{pH}$. This parameter is the key factor as it influences the chemistry of the metal ions, the protonation/ deprotonation of the functional groups of the cell wall, and the selectivity of the entrapment matrix toward different metallic ions in solution. ${ }^{[101,105,129-131]}$. These authors also evaluated the effects of several operational parameters, such as the solution $\mathrm{pH}$, in order to optimize the reduction and removal of $\mathrm{Cr}(\mathrm{VI})$ by the combined system $A$. viscosus/NaY zeolite. ${ }^{[19]}$ In this study, it was reported that the uptake of total chromium (Fig. 5) was enhanced by the increase of the solution $\mathrm{pH}$ in the range of $1-4$, being the highest uptake of total chromium $\left(13 \mathrm{mg}_{\mathrm{Cr}(\mathrm{VI})}\right.$ $\mathrm{g}_{\text {zeolite }}{ }^{-1}$ ) achieved at $\mathrm{pH} 4$. Bulk chemical analyses confirmed a high content of chromium in the zeolite, $0.90 \%$, for $\mathrm{pH} 4$.

The biosorption of $\mathrm{Cr}(\mathrm{VI})$ using $\mathrm{Y}$ and $\mathrm{ZSM}_{5}$ zeolites was also studied by Silva et al. ${ }^{[45]}$ In this work, the acidity and sodium content of the starting zeolites were modified by ion exchange treatments with $\mathrm{NaNO}_{3}$. With regard to total acidity, these authors reported that after the ion exchange treatments, the acidity decreased with the increasing of sodium content. The reduction and removal of $\mathrm{Cr}(\mathrm{VI})$ by Arthrobacter viscosus supported on the different $\mathrm{Y}$ and $\mathrm{ZSM}_{5}$ zeolites were evaluated. These authors reported that $\mathrm{Y}$ zeolites revealed to be more effective than ZSM5 zeolites in chromium uptake (Fig. 6). Due to the higher Si/Al ratio of ZSM5, these zeolites have a lower number of framework aluminum atoms and a lower amount of compensating cations. In agreement, these authors observed that the ion exchange capacity of ZSM5 zeolites for chromium was lower than that of $\mathrm{Y}$ zeolites. In this study, the best uptake value of total chromium, 


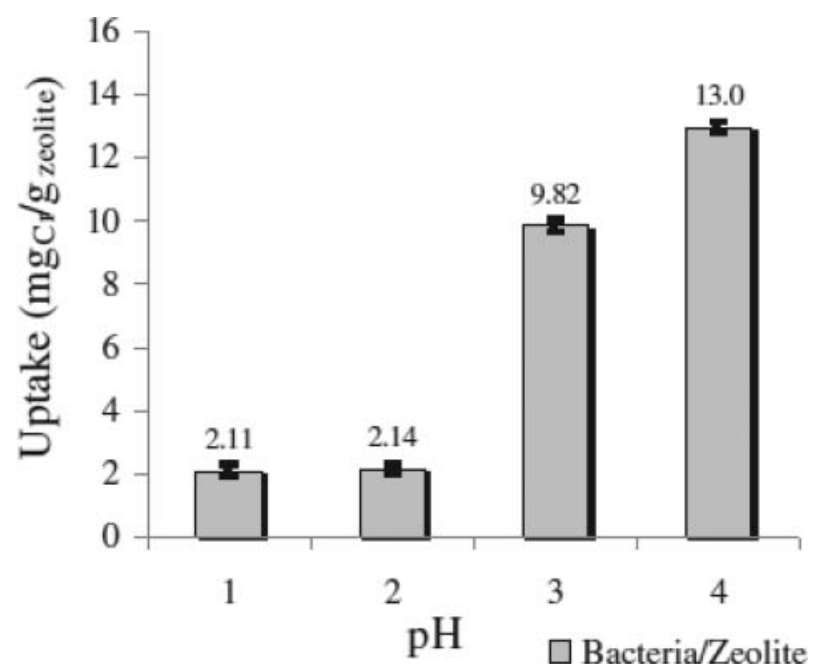

Figure 5. Uptake of total $\mathrm{Cr}$ by $A$. viscosus supported on $\mathrm{NaY}$ zeolite at $\mathrm{pH}$ values in the range of $1-4 .{ }^{[19]}$

(c) Elsevier. Reproduced by permission of Elsevier. Permission to reuse must be obtained from the rightsholder.

$14.6 \mathrm{mg}_{\mathrm{Cr}(\mathrm{VI})} \mathrm{g}_{\text {zeolite }}{ }^{-1}$, was achieved for the biosorption assay with $\mathrm{H}(\mathrm{Na})_{\mathrm{A}} \mathrm{Y}$, being $1.1 \%$ the final chromium content in the zeolite.

Figueiredo et al. ${ }^{[14]}$ studied the effect of the zeolitic support on the overall removal of $\mathrm{Cr}(\mathrm{VI})$, comparing two zeolitic structures with different chemical composition and ion exchange capacity: faujasite ( $\mathrm{HY}$ and $\mathrm{NaY}$ ) and mordenite (HMOR and NaMOR) zeolites. The performance of an A. viscosus biofilm supported in each different zeolite was evaluated in a single-step reactor and sequential batch reactor (SBR), during 27 days. For the single-step reactor studies, the authors observed that HY zeolite was the most effective when applied to low chromium

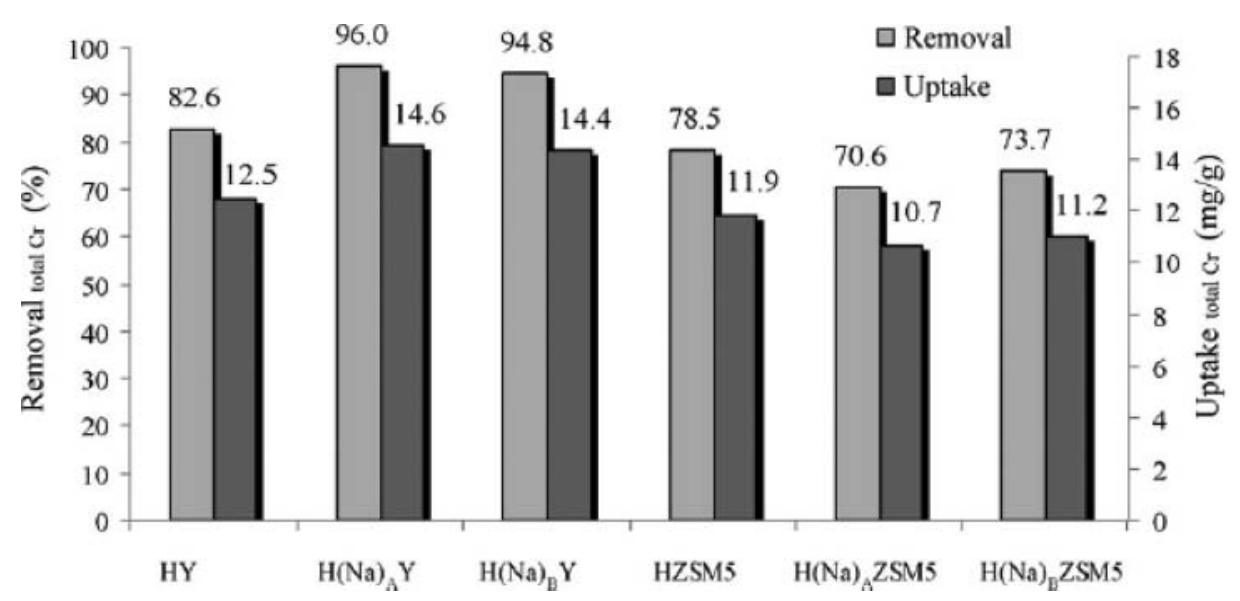

Figure 6. Removal efficiencies and uptake of total $\mathrm{Cr}$ for the biosorption assays performed with $A$. viscosus supported on Y and ZSM5 zeolites. ${ }^{[45]}$

(c) Elsevier. Reproduced by permission of Elsevier. Permission to reuse must be obtained from the rightsholder. 
Table 1. Cr removal and uptake for every system and all initial concentrations tested. ${ }^{[14]}$

\begin{tabular}{|c|c|c|c|c|}
\hline $\begin{array}{l}\text { Initial } \mathrm{Cr} \text { Concentration } \\
{\left[\mathrm{mg} \mathrm{L}^{-1}\right]}\end{array}$ & Zeolite & $\begin{array}{c}\text { Initial } \mathrm{Cr} \text { mass } \\
\text { in the reactor [mg] }\end{array}$ & $\begin{array}{c}\text { Cr uptake by the } \\
\text { system [mg g } \text { zeolite }^{-1} \text { ] }\end{array}$ & Cr removal [\%] \\
\hline \multirow[t]{4}{*}{50} & HY & 7.71 & 7.2 & 93.4 \\
\hline & $\mathrm{NaY}$ & & 7.0 & 90.8 \\
\hline & HMOR & & 6.0 & 77.8 \\
\hline & NaMOR & & 6.8 & 88.2 \\
\hline \multirow[t]{4}{*}{100} & HY & 15.08 & 10.8 & 71.6 \\
\hline & $\mathrm{NaY}$ & & 11.7 & 77.6 \\
\hline & HMOR & & 9.9 & 65.6 \\
\hline & NaMOR & & 9.5 & 63.0 \\
\hline
\end{tabular}

๑ Elsevier. Reproduced by permission of Elsevier. Permission to reuse must be obtained from the rightsholder.

concentrations (Cr uptake of $7.2 \mathrm{mg}_{\mathrm{Cr}(\mathrm{VI})} \mathrm{g}_{\text {zeolite }}{ }^{-1}$ ). However, for the higher chromium concentration, the best uptake was achieved by $\mathrm{NaY}$ zeolite $\left(11.7 \mathrm{mg}_{\mathrm{Cr}(\mathrm{VI})}\right.$ $\mathrm{g}_{\text {zeolite }}{ }^{-1}$ ), which has higher ion exchange capacity compared to HY zeolite (Table 1). These authors ${ }^{[14]}$ also studied the chromium retention ability of a SBR process for all zeolites. During the treatment process, the chromium was passed through three fresh biomass-zeolite reactors, with a residence time of four days in each reactor. The authors found that in SBR process, HY zeolite was the most efficient support with a $98.2 \%$ overall Cr removal (Table 2). On the other hand, NaY zeolite and MOR zeolites revealed similar removal performances, with removal efficiencies between $87.3 \%$ and $93.4 \%$. From the results obtained in this work, the authors concluded that the reduction of hexavalent chromium performed by the biomass is more suited to the dynamics of the SBR process.

\section{Metal-loaded zeolites as catalysts in oxidation reactions}

Zeolites are used in many reactions as catalysts: acid, basic, acid-basic, redox, and bifunctional. However, their great application is in the field of acid catalysis for hydrocarbon transformations. [24 26]

Zeolites can also be modified or synthesized for use in catalysis by inclusion of metal species in their structure. This can be achieved by two ways: a synthetic way, where isomorphic substitution of T atoms with selected metals is performed, and a postsynthetic way, consisting of a simple ion exchange with a salt of the desired

Table 2. Cr removal and uptake for every system tested at the different cycles, for the sequential batch reactor assays. ${ }^{[14]}$

\begin{tabular}{lcccc}
\hline & & \multicolumn{3}{c}{ Cr Uptake by the system $\left[\mathrm{mg} \mathrm{g}_{\text {zeolite }}{ }^{-1}\right]$} \\
\cline { 3 - 5 } Zeolite & Overall Cr removal [\%] & Cycle 1 & Cycle 2 & Cycle 3 \\
\hline HY & 98.2 & 8.3 & 5.2 & 0.3 \\
NaY & 87.3 & 6.7 & 4.6 & 0.4 \\
HMOR & 93.4 & 6.5 & 5.3 & 1.3 \\
NaMOR & 90.5 & 6.2 & 5.5 & 0.8 \\
\hline
\end{tabular}

๑ Elsevier. Reproduced by permission of Elsevier. Permission to reuse must be obtained from the rightsholder. 
metal or inclusion of the metal active center by grafting/tethering onto the zeolite surface or even by encapsulation of metal complexes into zeolitic structure. ${ }^{[132]}$ The insertion of catalytically active metal species offers the possibility of operating bifunctional catalysts. Ion exchange with transition metal cations or complexes is also a possible way of forming stable heterogeneous catalysts, while grafting and tethering (covalent bonding of the metal to the zeolite) are some of the most used techniques for the preparation of stable asymmetric catalysts. ${ }^{[133]}$

\subsection{Catalytic oxidation in gas phase}

Volatile organic compounds (VOC) are recognized as major contributors to air pollution either, through their toxic nature and/or acting as precursors of ozone and photochemical smog. ${ }^{[134]}$ VOC are commonly found in the atmosphere at ground level and can include a variety of substances, namely hydrocarbons, olefins, aromatics, and various oxygen-, nitrogen-, sulfur-, and halogen-containing compounds. ${ }^{[135]}$

The control of VOC emissions into the atmosphere is of particular concern because they are a main component in the chemical and physical atmospheric reactions that form ground-level (tropospheric) ozone and other photochemical oxidants. ${ }^{[135]}$ Ground-level ozone is the major component of photochemical smog, and it is generated in situ from the sunlight-initiated oxidation of VOC, in the presence of nitrogen oxides, NOx. ${ }^{[136]}$ High concentrations of tropospheric ozone cause irritation of the respiratory system and the reduction of the lung function, as well as they increase the susceptibility to respiratory infections. Moreover, some VOC are considered to be toxic and/or carcinogenic to human health. The release of VOC into the environment has also been associated with the stratospheric ozone depletion and enhancement of the global greenhouse effect. ${ }^{[137]}$

Catalytic oxidation is one of the most promising technologies for the reduction of VOC, since it allows their abatement at low temperatures and offers high destructive efficiencies with low capital cost within small units. ${ }^{[138]}$ This process has been extensively studied in the last decades by several authors. ${ }^{[139-142]}$

The use of heterogeneous catalysts for the oxidation of industrial vapors and gases is a very well-studied field. The heterogeneous catalytic processes can be classified in two different categories: partial oxidation and complete oxidation. In the partial oxidation processes, the main goal is the production of industrially important partially oxidized products. ${ }^{[142,143]}$ On the other hand, the complete oxidation processes are used to degrade organic contaminants in air like industrial emissions or automotive exhaust gases. These two different fields of catalytic oxidations have quite different operation conditions in order to obtain the desired products. The complete catalytic oxidation of VOC is carried out at atmospheric pressure, with low reactant concentration and with excess of oxygen to promote the production of $\mathrm{CO}_{2}$ and $\mathrm{H}_{2} \mathrm{O}$. In opposition, the formation of such products is undesired in partial oxidation reactions. One of the most important aspects in this kind of process is to choose the adequate catalyst, taking into account several variables, such 
as the type of effluent to be treated and the presence of contaminants (like sulfur compounds) that can poison the catalyst. The selected catalyst should be highly active, so that the reaction might be carried out at low temperatures and to favor the formation of total oxidation products. If the oxidation of VOC is not complete, the formation of even more toxic compounds than those being treated may occur.

The efficiency of the catalytic oxidation process is dependent on the type of VOC to be treated. Due to their nature, each VOC has different reactivity, and therefore, the total oxidation is attained at different temperatures for each of them. The adsorption strength, as well as the structure of each VOC, is on the basis of their reactivity toward oxidation. Yao ${ }^{[144]}$ studied the reactivity of $\mathrm{C} 1-\mathrm{C} 4$ alkanes over typical $\mathrm{Pt} / \mathrm{Al}_{2} \mathrm{O}_{3}$ and $\mathrm{Pd} / \mathrm{Al}_{2} \mathrm{O}_{3}$ catalysts and obtained a clear order of destructibility with butane being the easiest to oxidize and methane the hardest. Later, Hermia and Vigneron ${ }^{[145]}$ studied the oxidation of several VOC, with different functional groups, over a $\mathrm{Pt} / \mathrm{Al}_{2} \mathrm{O}_{3}$ catalyst and reported the following order of reactivity: alcohols $>$ aldehydes $>$ aromatics $>$ ketones $>$ alkenes $>$ alkanes. Several authors ${ }^{[146,147]}$ defended that the weakest $\mathrm{C}-\mathrm{H}$ bond rupture is the determining step in the oxidation of saturated hydrocarbons, in which the substrate is activated on the metal surface. The species formed react rapidly with surface oxygen to yield total oxidation products. For this reason, a single weak bond leads to high reactivity.

It is important to note that the oxidation of VOC, in particular oxygenated compounds, can lead to the formation of partial oxidation compounds, and therefore, it is important to know the reactivity of these by-products. For instance, over a $\mathrm{Pt} / \mathrm{Al}_{2} \mathrm{O}_{3}$ catalyst, the oxidation of ethanol can produce acetaldehyde and acetic acid as by-products, ${ }^{[148]}$ whereas the oxidation of ethyl acetate can form acetic acid and ethanol as primary products, and acetone, acetaldehyde, diethylether, and ethylene as secondary products. ${ }^{[149]}$

It is well known that supports may significantly affect the activity of the catalysts in oxidation reactions. Zeolitic materials can be used either as supports for noble metals or otherwise can be loaded with transition metal ions by ion exchange. Several research studies have reported the use of zeolite-supported noble metals catalysts for the oxidation of several VOC. ${ }^{[29,33,150-152]}$ Particular attention has been given to the replacement of noble metals by low-cost transition metals, such as $\mathrm{Cr}$, $\mathrm{Co}, \mathrm{Cu}$, and $\mathrm{Ni}$. In the last decade, numerous studies have been carried out in order to investigate the properties of transition metal exchanged or impregnated zeolite catalysts in VOC oxidation. ${ }^{[39-41,43-45,153-155]}$ Moreover, adsorption plays an important role on the catalytic process, and zeolites may act as a dual functional adsorbent/catalyst system for VOC removal. In these particular systems, VOC may be removed simultaneously by adsorption and catalysis. ${ }^{[152,156,157]}$

Silva et al. ${ }^{[4]}$ studied the reutilization of Cr-loaded Y zeolites, obtained by biosorption of $\mathrm{Cr}(\mathrm{VI})$, in the catalytic oxidation of ethyl acetate, ethanol, and toluene. For these studies, the authors selected the Cr-Y zeolite obtained after the biosorption at $\mathrm{pH} 4$ as the best catalyst for the oxidation of VOC due the high content of 
Table 3. Temperatures corresponding to $100 \%$ of VOC conversion $\left(\mathrm{T}_{100}\right)$ and maximum $\mathrm{CO}_{2}$ yield, using $\mathrm{Cr}-\mathrm{Y}$ catalyst. ${ }^{[44]}$

\begin{tabular}{lccc}
\hline VOC & $\mathrm{T}_{100 \%}\left[{ }^{\circ} \mathrm{C}\right]^{(\mathrm{a})}$ & $\mathrm{X}_{\text {CO2 }}[\%]$ & $\mathrm{T}\left[{ }^{\circ} \mathrm{C}\right]^{(\mathrm{b})}$ \\
\hline Ethyl acetate & 385 & 100 & 520 \\
Ethanol & 355 & 39 & 450 \\
Toluene & 450 & 70 & 450 \\
\hline
\end{tabular}

(a) Temperatures for complete conversion of VOC.

${ }^{(b)}$ Temperatures for the maximum conversion into $\mathrm{CO}_{2}$.

๑ Elsevier. Reproduced by permission of Elsevier. Permission to reuse must be obtained from the rightsholder.

chromium $(0.90 \%)$. These authors verified that the catalyst with chromium showed higher activity and selectivity toward $\mathrm{CO}_{2}$, compared to the parent $\mathrm{NaY}$ zeolite. Table 3 summarizes the temperatures corresponding to the complete conversion of VOC $\left(\mathrm{T}_{100 \%}\right)$ and the maximum conversion into $\mathrm{CO}_{2}\left(\mathrm{X}_{\mathrm{CO} 2}\right)$, for each compound tested. In terms of VOC conversion, the authors observed the following sequence: ethanol $>$ ethyl acetate $>$ toluene. On the other hand, the authors found that ethyl acetate was the only compound for which total oxidation was attained. With respect to selectivity toward $\mathrm{CO}_{2}$, the order observed was ethyl acetate $>$ toluene $>$ ethanol.

These authors stated that the presence of chromium not only increased the activity and selectivity of the catalyst but also shifted the reaction pathways. According to the author's statements, the possible reaction mechanisms for the different VOC and catalysts (Cr-Y and NaY) can be represented by Scheme 1a), 1b), and 1c).

Silva et al. ${ }^{[45]}$ also studied the catalytic reutilization of different Y and ZSM5 zeolites obtained after biosorption of chromium in the oxidation of ethyl acetate. The samples Cr-HY (1.10\% Cr), Cr-H(Na) $)_{\mathrm{B}} \mathrm{Y}(1.20 \% \mathrm{Cr}), \mathrm{Cr}-\mathrm{HZSM} 5$ (0.93\% Cr), and $\mathrm{Cr}-\mathrm{H}(\mathrm{Na})_{\mathrm{B}} \mathrm{ZSM} 5(0.92 \% \mathrm{Cr})$ showed good performances in the complete oxidation of ethyl acetate. The authors reported that the ZSM5 catalysts had higher activity and selectivity toward $\mathrm{CO}_{2}$ than $\mathrm{Y}$ zeolites (Table 4). In addition, the authors concluded that extension of sodium exchange did not significantly affect the catalytic properties of the zeolites, since Y and ZSM5 catalysts with different content of sodium had similar catalytic behaviors.

With these studies, ${ }^{[4,45]}$ it was demonstrated that the introduction of chromium, a transition metal, into supports with catalytic properties, such as zeolites, brings some important advantages in oxidation reactions, due to their remarkable properties in terms of shape selectivity, pore structure, and acidity. The activity and selectivity of the zeolites loaded with chromium were significantly higher in comparison with the parent zeolites. The reoxidation of $\mathrm{Cr}$ (III) at oxidative conditions, during the calcination of samples after the biosorption treatments, was demonstrated by the authors through a $\mathrm{H}_{2}$-TPR experiment. ${ }^{[4]}$ This is a key aspect in the use of chromium-loaded catalysts in oxidation reactions 
(a)

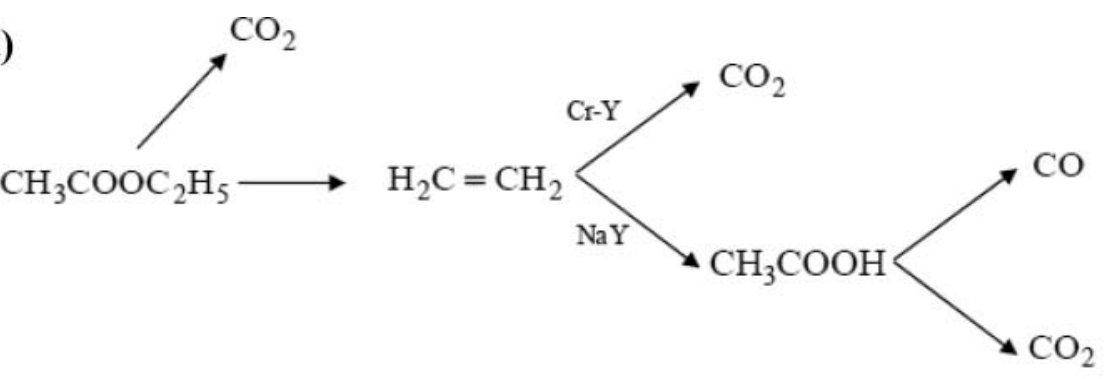

(b)

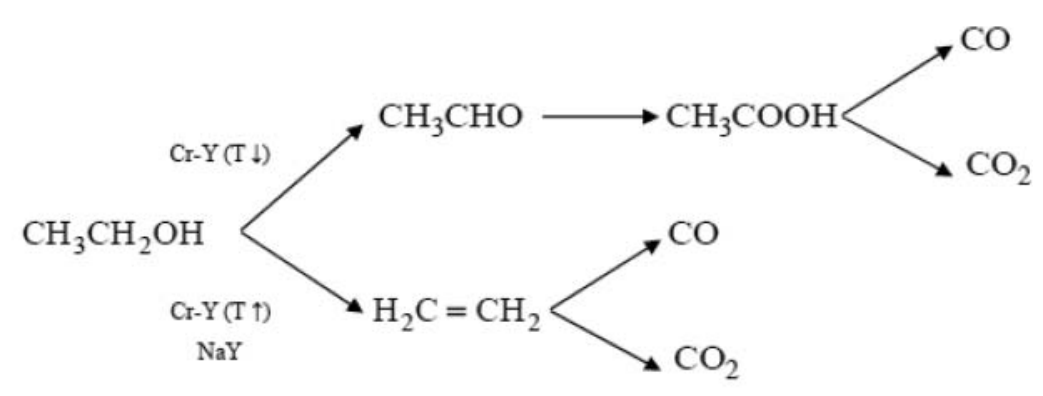

(c)

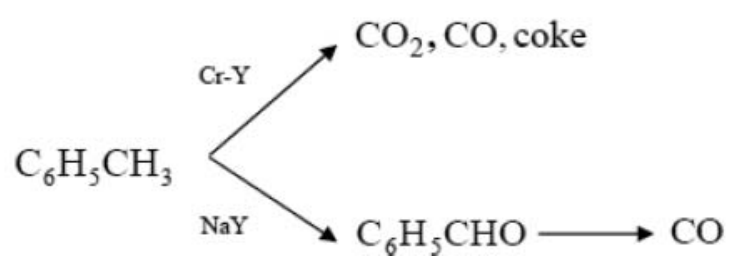

Scheme 1. Possible reaction pathways for ethyl acetate (a), ethanol (b), and toluene (c) oxidation on $\mathrm{Cr}-\mathrm{Y}$ and $\mathrm{NaY}$ catalysts.

\subsection{Catalytic oxidation in liquid phase}

The oxidation of organic compounds is one of the most important processes in chemical industry, namely in the field of organic synthesis. ${ }^{[158]}$ For instance, the formation of $\mathrm{C}-\mathrm{OH}$ or $\mathrm{C}=\mathrm{O}$ bonds by oxidation of $\mathrm{C}-\mathrm{H}$ or $\mathrm{C}-\mathrm{C}$ bonds, respectively, allows the generation of precursors, which can be then transformed into value-added products. ${ }^{[159]}$ Nevertheless, the inefficiency associated with the oxidation reaction process can be overcome by the use of Table 4. Temperatures corresponding to $100 \%$ of ethyl acetate conversion and maximum yield of $\mathrm{CO}_{2} \cdot{ }^{[45]}$

\begin{tabular}{lccc}
\hline Catalyst & $\mathrm{T}_{100 \%}\left({ }^{\circ} \mathrm{C}\right)^{(\mathrm{a})}$ & $\mathrm{X}_{\mathrm{CO} 2}(\%)$ & $\mathrm{T}\left({ }^{\circ} \mathrm{C}\right)^{(\mathrm{b})}$ \\
\hline $\mathrm{Cr}-\mathrm{HY}$ & 483 & 41 & 500 \\
$\mathrm{Cr}-\mathrm{H}(\mathrm{Na})_{\mathrm{B}} \mathrm{Y}$ & 440 & 45 & 520 \\
$\mathrm{Cr}-\mathrm{HZSM} 5$ & 371 & 87 & 520 \\
$\mathrm{Cr}-\mathrm{H}(\mathrm{Na})_{\mathrm{B}} \mathrm{ZSM} 5$ & 375 & 83 & \\
\hline
\end{tabular}

\footnotetext{
(a) Temperatures for complete conversion of ethyl acetate.

(b) Temperatures for the maximum conversion into $\mathrm{CO}_{2}$.

(c) Elsevier. Reproduced by permission of Elsevier. Permission to reuse must be obtained from the rightsholder.
} 
suitable catalytic processes, namely those which use eco-friendly oxidants like $\mathrm{H}_{2} \mathrm{O}_{2}, \mathrm{O}_{2}$, and $\mathrm{RO}_{2} \mathrm{H}$ in replacement of hazardous oxidants, such as $\mathrm{KMnO}_{4}$ and $\mathrm{K}_{2} \mathrm{Cr}_{2} \mathrm{O}_{7} \cdot{ }^{[160,161]}$

The catalytic oxidation in liquid phase has been largely applied in chemical industry processes. In the past few decades, it was not common to associate the oxidation in liquid phase with heterogeneous catalysis. ${ }^{[47]}$

Since the development of titanium silicalite-1 (TS-1) at the beginning of the 1980s by Taramasso et al., ${ }^{[162]}$ a zeolitic-type material with MFI structure, several research studies were done in the field of heterogeneous catalysis. Several research studies demonstrated a great motivation in the field of synthesis, characterization, and application of a large variety of new metal-substituted molecular sieves, supported transition-metal complexes, and noble metal nanoparticles catalytically active for oxidation reactions. In the last two to three decades, the area of catalysis related to liquid-phase oxidations has achieved a remarkable progress, from both a scientific and industrial perspective. ${ }^{[4]}$

\subsubsection{Immobilization of metal complexes into zeolites}

The utilization of metal-zeolite catalysts in liquid-phase oxidation reactions requires previous immobilization of the metal species in the support, in order to overcome the possible metal leaching. ${ }^{[132,158,163]}$ Several methods have been proposed for the immobilization of metal centers with catalytic activity in inorganic structures. Some strategies to synthetize heterogeneous catalysts involve the coordination of the metal with ligands by anchoring it to the support or otherwise can be performed by in situ synthesis, with immobilization and encapsulation of the complex inside the host, ${ }^{[50,51,133,164]}$ as presented in Fig. 7 . The immobilization and encapsulation of metal complexes inside solid supports have become important methods in the field of environmentally friendly industrial processes. ${ }^{[50-52,165-167]}$

Encapsulated metal complexes are somewhat different from other metal-zeolite catalysts, as in this case there is no physical interaction between the metal complex and the host, which will eliminate possible interferences in the electronic environment of the central metal ion. ${ }^{[133]}$ The encapsulation of metal complexes can be achieved by in situ assembly of the complex or by the crystallization of the zeolite

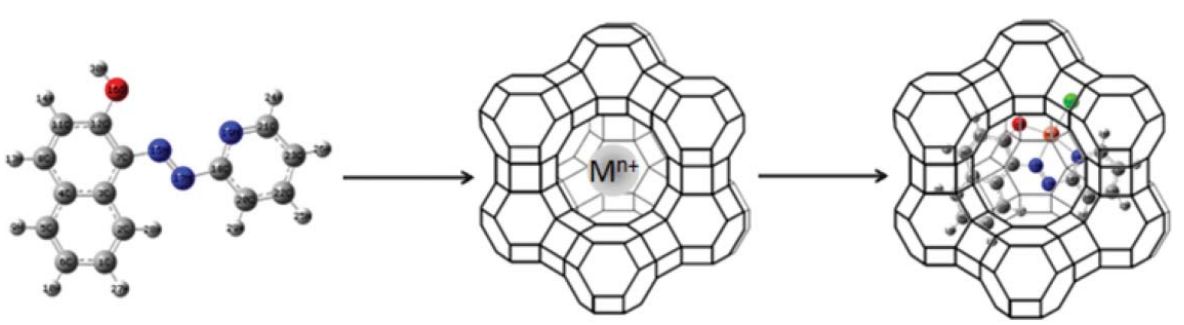

Figure 7. Metal complex based in 1-(2-pyridylazo)-2-naphthol immobilized into a FAU zeolitic cavity by in situ synthesis. 
around the previously formed complex. ${ }^{[50]}$ Both approaches have specific requirements to be successfully implemented.

The in situ synthesis requires that the size of ligand molecules used for the coordination with the metal ions is such that it allows them to diffuse through the zeolite pores and, upon coordination, the bulk volume of the complex obtained becomes larger, preventing the leaching of the metal. ${ }^{[133]}$ This process is called the flexible ligand method, also known as ship-in-a-bottle synthesis (Fig. 7).

\subsubsection{Chromium as catalyst for oxidation reactions}

According to Muzart, ${ }^{[168]}$ chromium has been used as catalyst in the field of oxidation reactions since the dawn of organic synthesis. This author presented a comprehensive view of the uses of homogeneous $\mathrm{Cr}$ catalysts in several types of organic oxidation reactions, distinguishing between the different formal oxidation states while keeping larger focus on $\mathrm{Cr}(\mathrm{III})$ - and $\mathrm{Cr}(\mathrm{VI})$-catalyzed reactions. Despite the known problems associated with the toxicity of this metal, coupled to the possible difficulties in the end-of-reaction recovery or disposal of the catalyst, the author pointed out the great activity and versatility of chromium catalysts. Reckoned homogenous $\mathrm{Cr}$-based catalysts are the Jones reagent $\left(\mathrm{CrO}_{3}, \mathrm{H}_{2} \mathrm{SO}_{4}\right.$, and acetone), the Collins reagent $\left(\mathrm{CrO}_{3}\right.$ and pyridine), and the PCC reagent $\left(\mathrm{CrO}_{3}\right.$, pyridine, and $\left.\mathrm{HCl}\right){ }^{[169]}$

Weckhuysen et al. ${ }^{[170]}$ have commented on the application of supported Cr catalysts in several reactions, from olefin oxidation to polymerization and hydrogenation-dehydrogenation of alkanes. Concerning the authors' comments on olefin oxidation, $\mathrm{Cr}$ catalysts are very active in the oxidation of alcohols, although $\mathrm{Cr}$ (VI) oxide proved to be a much more active catalyst than $\mathrm{Cr}$ (III) oxide in the oxidation of methanol. Cr-aluminophosphate molecular sieves (Cr-APO) were referred as excellent catalysts for the oxidation of secondary alcohols with tert- butyl hydroperoxide $(t-\mathrm{BuOOH})$ as oxygen source. The authors also commented on the activity of heterogeneous $\mathrm{Cr}$ catalysts on amorphous supports for hydrocarbons oxidation.

Although the usefulness of $\mathrm{Cr}$ heterogeneous catalysts is acknowledged, the actual degree of heterogeneity in these catalysts is still subject of some debate. Arends and Sheldon ${ }^{[132]}$ and Sheldon et al. ${ }^{[163]}$ have reported several works on the subject of $\mathrm{Cr}$ leaching from heterogeneous catalysts. According to the authors, even framework-substituted catalysts, such as Cr-APOs molecular sieves, present loss of $\mathrm{Cr}$ ions into the solution when in contact with alkylhydroperoxide oxidants $\left(\mathrm{RO}_{2} \mathrm{H}\right)$, which led to the breakdown of $\mathrm{Al}-\mathrm{O}-\mathrm{Cr}$ and $\mathrm{Si}-\mathrm{O}-\mathrm{Cr}$ bonds. Lounis et al. ${ }^{[158]}$ used a $\mathrm{Cr}$ (III) ion-exchanged ZSM5 zeolite as catalyst for the oxidation of several alcohols with $t$ - $\mathrm{BuOOH}$ and reported the leaching of $\mathrm{Cr}$ species during heating of the reaction mixture. The authors indicated the complexation of $\mathrm{Cr}$ with the alkyl peroxide to be responsible for the leaching of the metal species, as it led to the formation of a soluble complex. However, the authors also observed the readsorption of part of the leached species during the cooling down of the reaction 


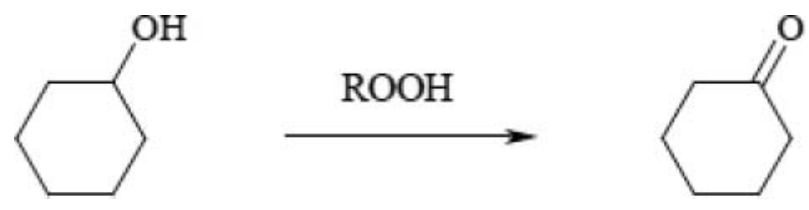

Scheme 2. Peroxide oxidation of cyclohexanol into cyclohexanone.

mixture. Cruz et al. ${ }^{[171]}$ and Spinacé et al. ${ }^{[49]}$ reported the preparation and test of $\mathrm{Cr}$ (III)-silicate catalyst and also observed the homogenous character due to leached $\mathrm{Cr}$ ions in the liquid-phase oxidation of cyclohexane with $t$ - $\mathrm{BuOOH}$ and/or in the oxidation of cyclohexane with hydrogen peroxide. The authors concluded that the loss of $\mathrm{Cr}$ was due to solvolysis of the $\mathrm{Cr}-\mathrm{O}$ bonds from the support with polar compounds, such as water or peroxides.

\subsubsection{Catalytic oxidation of cyclohexanol and cyclohexene}

The oxidation reactions of cyclohexene and cyclohexanol are somewhat different in nature, as cyclohexene is an olefin, while the oxidation of cyclohexanol takes the common pathway for the oxidation of a secondary alcohol, with the formation of the ketone derivative, as illustrated in Scheme 2.

The production of cyclohexanone has particular industrial interest since this compound is a precursor to the production of nylon- 6 and nylon-6,6. ${ }^{[161]}$

Catalysts containing hexavalent $\mathrm{Cr}$ derivatives are very active in the oxidation of cyclohexanol. ${ }^{[172,173]}$ The associated problems of toxicity and catalyst recovery have led to the developments of heterogeneous catalysts. Since $\mathrm{Cr}(\mathrm{VI})$ is an active catalyst for this reaction, some authors reported the preparation of heterogeneous catalysts, which employed this metal ion. An interesting work was reported by Parentis et al. ${ }^{[174]}$ who studied the oxidation of cyclohexanol with $t$-BuOOH in the presence and in the absence of molecular oxygen, using a $\mathrm{Cr}(\mathrm{III})$ silica-supported catalyst. The authors concluded that the presence of $\mathrm{O}_{2}$ increases overall conversion of cyclohexanol, although the reaction can take place in its absence, even with a slightly lower conversion. Moreover, $\mathrm{O}_{2}$ was considered a cooxidant, since when in absence of tert- butyl hydroperoxide, molecular oxygen was not able to induce any oxidation of cyclohexanol, the alkyl peroxide was the initiator of the reaction. The authors also proposed the following reaction mechanism (Scheme 3).

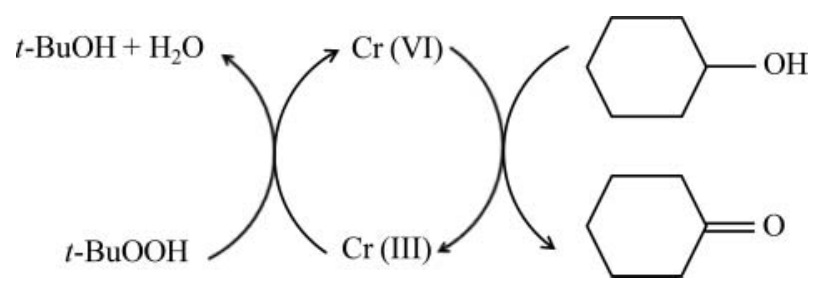

Scheme 3. Proposed mechanism by Parentis et al. ${ }^{[174]}$ of cyclohexanol oxidation with $t$-BuOOH using $\mathrm{Cr}$ catalysts. 


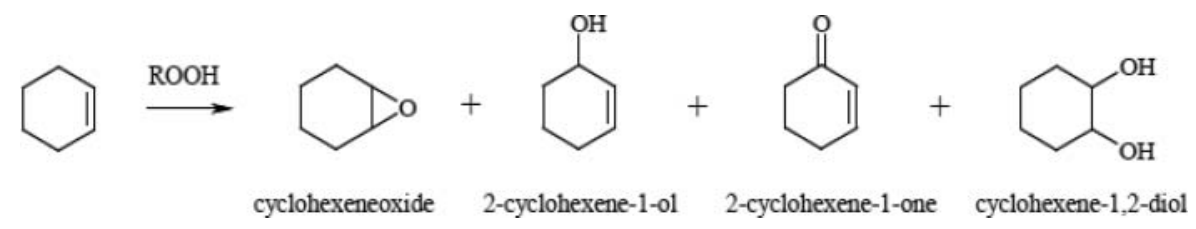

Scheme 4. Main reaction products of the cyclohexene oxidation.

The research into developing heterogeneous $\mathrm{Cr}$ catalysts for this reaction led to different approaches. A report on the use of $\mathrm{Cr}$ oxides was presented by Nakamura and Matsuhashi, ${ }^{[169]}$ who employed $\mathrm{Cr}(\mathrm{VI})$ oxides supported in zirconia $\left(\mathrm{CrO}_{3} /\right.$ $\mathrm{ZrO}_{2}$ ) as efficient heterogeneous catalysts. Isomorphic $\mathrm{Cr}$-substituted molecular sieves have also been tested for the oxidation of cyclohexanol, as it was reported by Laha and Gläser. ${ }^{[175]}$ The authors reported the synthesis of $\mathrm{Cr}$ (III)-containing MCM and APO molecular sieves, named CrMCM-41, CrMCM-48, and CrAPO-5. The catalytic tests showed activity for the reaction. However, there was some leaching of $\mathrm{Cr}$ species into the reaction medium, with higher incidence on the mesoporous MCM-based catalyst than in the microporous APO counterpart.

Compared to the oxidation of cyclohexanol, cyclohexene has a more intricate oxidation behavior, with the competition of $\mathrm{C}-\mathrm{H}$ and $\mathrm{C}=\mathrm{C}$ bonds for the active oxidant. ${ }^{[160]}$ This reaction may yield a significant number of products, the most common are presented in Scheme 4.

The activity of $\mathrm{Cr}$ catalysts in this reaction is not as widely recognized as in the case of the oxidation of cyclohexanol. However, some authors presented the successful use of Cr catalysts. As early as 1994, Bautista et al. ${ }^{[176]}$ reported the use of mixed $\mathrm{CrPO}_{4}-\mathrm{AlPO}_{4}$ in the oxidation of cyclohexene. Sakthivel et al. ${ }^{[177,178]}$ published reports on the use of CrMCM molecular sieves as interesting catalysts for the oxidation of olefins, which were subsequently tested for the oxidation of cyclohexene with $t$-BuOOH. The authors proposed a free radical mechanism to be responsible for the reaction, with $\mathrm{Cr}$ radical centers being generated by the peroxide action. Cr supported on silica was also tested by Adam and Fook, ${ }^{[179]}$ using silica from rice husk and a $\mathrm{Cr}$ (III) solution in the synthesis gel. The catalysts were tested on the oxidation of cyclohexane and cyclohexene with $\mathrm{H}_{2} \mathrm{O}_{2}$, being comparatively as active as other high-surface area heterogeneous catalysts.

Works on the use of $\mathrm{Cr}$ complexes encapsulated in zeolites have been recently reported. Salavati-Niasari, ${ }^{[180]}$ Salavati-Niasari et al., ${ }^{[181]}$ Salavati-Niasari, and Abdolmohammadi ${ }^{[182]}$ have devoted their work to the preparation of this type of catalysts for reactions, such as cyclohexene oxidation, studying different metals, and supports, although recurrently using $\mathrm{Y}$ zeolite for the encapsulation of the metal complexes. In a recent study, Abbo and Titinchi ${ }^{[183]}$ reported the in situ synthesis of $\mathrm{Cr}(\mathrm{III}), \mathrm{Zn}$ (II), and $\mathrm{Ni}$ (II) thio-Schiff base complexes in Y zeolite. The authors conducted the oxidation of cyclohexene with $\mathrm{H}_{2} \mathrm{O}_{2}$ at $80{ }^{\circ} \mathrm{C}$ and observed that both $\mathrm{Ni}$ and $\mathrm{Cr}$ encapsulated complexes present good activity for the reaction, achieving more than $70 \%$ conversion, whereas the $\mathrm{Zn}$ counterpart was not active. 


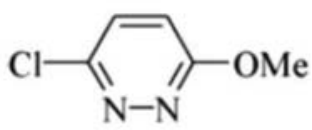

(a)

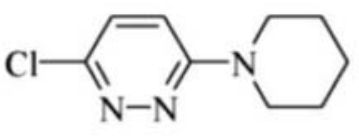

(b)<smiles>Oc1ccc2ccccc2c1N=Nc1ccccn1</smiles>

(c)

Scheme 5. Structures of the ligands: (a) 3-methoxy-6-chloropyridazine, (b) 3 piperidino-6-chloropyridazine, and (c) 1-(2-pyridylazo)-2-naphthol. ${ }^{[42]}$

(c) Elsevier. Reproduced by permission of Elsevier. Permission to reuse must be obtained from the rightsholder.

Figueiredo et al. ${ }^{[42]}$ evaluate the catalytic behavior of $\mathrm{Cr}$ complexes immobilized within Y zeolite, in the oxidation of cyclohexene in liquid phase. The catalysts were previously obtained from biosorption of $\mathrm{Cr}(\mathrm{VI})$, using a bacterial biofilm supported on NaY zeolite. The catalytic oxidation of cyclohexene was performed in liquid phase, at $40^{\circ} \mathrm{C}$, using tert-butyl hydroperoxide as oxygen source. The immobilization of $\mathrm{Cr}$ complexes in the supercages of $\mathrm{Y}$ zeolite was performed by the in situ synthesis with three different pyridazine ligands (Scheme 5). The identified reaction products were 2-cyclohexene-1-ol (CyOL), 2-cyclohexene-1 one (CyONE), and 1-tert-butylperoxy-2-cyclohexene (CyOX), which are the typical expected products for this reaction. ${ }^{[180,184-186]}$ The catalytic results are summarized in Table 5.

These authors observed that the presence of $\mathrm{Cr}$ in $\mathrm{NaY}$ prepared from two different methods (biosorption and ion exchange) resulted in the improvement of conversion and selectivity. A high conversion of cyclohexene was observed when sodium is ion-exchanged with $\mathrm{Cr}(\mathrm{III})$ in NaY. However, $\mathrm{CrNaY}$ obtained by biosorption process exhibited a significant higher turnover number, TON, in comparison with $\mathrm{Cr}(\mathrm{III}) \mathrm{NaY}$, suggesting that chromium obtained

Table 5. Data from oxidation of cyclohexene with TBHP for different catalysts (reaction time $=24$ h). ${ }^{[42]}$

\begin{tabular}{|c|c|c|c|c|c|}
\hline \multirow[b]{2}{*}{ Catalyst } & \multirow[b]{2}{*}{ Conversion [\%] } & \multicolumn{3}{|c|}{ Selectivity [\%] } & \multirow[b]{2}{*}{$\operatorname{TON}^{(a)}$} \\
\hline & & $\mathrm{CyOL}^{(\mathrm{b})}$ & CyONE ${ }^{(c)}$ & CyOx $x^{(d)}$ & \\
\hline - & 16.2 & - & - & 100.0 & - \\
\hline $\mathrm{NaY}$ & 14.2 & - & - & 100.0 & - \\
\hline $\mathrm{CrNaY}$ & 40.3 & - & 34.3 & 65.7 & 614 \\
\hline $\mathrm{Cr}(\mathrm{III}) \mathrm{NaY}$ & 51.2 & 20.1 & 79.9 & - & 160 \\
\hline$\left[\mathrm{CrL}_{\mathrm{A}}\right]_{1}-\mathrm{NaY}$ & 27.6 & - & 17.0 & 83.0 & 647 \\
\hline$\left[\mathrm{CrL}_{\mathrm{B}}\right]_{2}-\mathrm{NaY}$ & 30.3 & - & 18.4 & 81.6 & 717 \\
\hline$\left[\mathrm{CrL}_{\mathrm{C}}\right]_{3}-\mathrm{NaY}$ & 31.8 & - & 21.5 & 78.5 & 851 \\
\hline$\left[\mathrm{Cr}(\mathrm{III}) \mathrm{L}_{\mathrm{A}}\right]_{4}-\mathrm{NaY}$ & 37.9 & 9.5 & 44.5 & 46.0 & 137 \\
\hline
\end{tabular}

(a) TON $=$ the converted cyclohexene $(\mathrm{mol}) /$ the amount of metal ions in the added catalyst (mol).

${ }^{\text {(b) }} \mathrm{CyOL}$ is 2-cyclohexene-1-ol product.

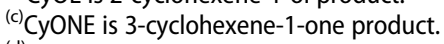

${ }^{\text {(d) }} \mathrm{CyOX}$ is 1-tert-butylperoxy-2-cyclohexene product.

(e) Host obtained by biosorption method.

${ }^{(f)}$ Host obtained by ion exchange method.

(c) Elsevier. Reproduced by permission of Elsevier. Permission to reuse must be obtained from the rightsholder. 


$$
\left(\mathrm{CH}_{3}\right)_{3} \mathrm{COOH}+\left[\mathrm{Cr}^{\mathrm{II}}\right]-\mathrm{Na} \longrightarrow\left[\mathrm{Cr}^{\mathrm{IV}}(\mathrm{OH}) \mathrm{L}\right] \mathrm{NaY}+\left(\mathrm{CH}_{3}\right)_{3} \mathrm{CO}
$$

Scheme 6. Reaction mechanism for the oxidation of cyclohexene. ${ }^{[42]}$

(c) Elsevier. Reproduced by permission of Elsevier. Permission to reuse must be obtained from the rightsholder.

by biosorption is accessible and active for the oxidation reaction. The authors reported that the reaction mechanism proposed for the formation of 2-cyclohexene-1-ol and 2-cyclohexene-1-one is more associated with the cage controlled metal-OH chemistry rather than to free radical mechanism. The authors stated that the formation of 1-tert-butylperoxy-2-cyclohexene proceeds through a radical mechanism, represented in Scheme 6. ${ }^{[180,184-189]}$ Figueiredo and coworkers concluded with this work that the results obtained open a new perspective to prepare active catalysts to be applied in the oxidation of persistent organic compounds by using heavy metals recovered from wastewater by a biosorption system consisting of a bacterial biofilm, Arthrobacter viscosus, supported on $\mathrm{NaY}$ zeolite.

\section{Future prospects and conclusions}

In the last years, many efforts have been done in the development of alternative low-cost technologies for heavy metals removal from industrial effluents. Among these, biosorption by bacterial biomass, as well as ion exchange performed by zeolites, appears to be advantageous solutions in comparison with 
conventional techniques. This review is focused on a conjugate treatment technology, combining the biosorption properties of a bacterium with the ion exchange capacity of a zeolite, that demonstrated to be capable of efficiently accumulate $\mathrm{Cr}(\mathrm{VI})$. In this particular system, the chemical reduction ability of the bacterium allowed the removal of anionic chromium species from solution, such as chromate and dichromate, and the incorporation of the metal into the zeolite, which would not be feasible by the zeolite itself.

The introduction of transition metal ions into supports with catalytic properties, such as zeolites, has gained particular interest in the field of catalytic oxidation of organic compounds. The studies presented in this review demonstrate that the chromium-loaded zeolites obtained from the biosorption process were successfully reused as catalysts for the oxidation of VOC, namely ethyl acetate, ethanol, and toluene, and for the oxidation of cyclohexene in liquid phase. In all the referred publications, the activity of the zeolites loaded with chromium was markedly higher in comparison with the parent zeolites.

The development of a biosorption-based process for the treatment of $\mathrm{Cr}(\mathrm{VI})$ contaminated water, which endowed the recovery and reuse of the metal, led to the successful application of what would be considered as a waste in environmental catalytic oxidation reactions.

With a theme as broad and transversal as the presented in this review, there are numerous areas where new approaches can be made. Several interesting directions of research regarding simultaneously the recovery of metals by biosorption and their catalytic reutilization in oxidation reactions should be therefore continued. Firstly, the choice of zeolitic support could be further explored, so it would be of interest the study of the effect of zeolitic structures with different $\mathrm{Si} / \mathrm{Al}$ ratio and pore opening on the uptake of different metals and in their further catalytic reutilization. Also, the application of specific natural zeolites could be considered in order to decrease the overall cost of the system. Another feature worth exploring is the operation with open systems or with flow reactors in detriment of the batch operation. To enhance the perspectives of the biotreatment capacities of the system, another aspect needing evaluation is the test with multimetal solutions. Some metal ions are prone to the formation of chemical sludge when in the presence of dichromate anions, and it would be interesting to evaluate the reduction of the formed metalchromate and metal-dichromate anions. Another interesting application of the system would be the treatment of real effluents containing heavy metals and organic compounds/solvents.

With regard to catalytic oxidation reactions of VOC, it would be interesting to perform long duration experiments in order to evaluate the stability of the catalysts. In the same research line, the investigation of the deactivation mechanisms and coke formation during the reactions is also an important issue that could be considered in further experiments. The evaluation of different VOC with environmental significance, such as chlorobenzene derivatives, as 
well as the study of two and three component VOC mixtures, would be of great interest.

In terms of the reutilization of the Cr-containing zeolites as catalysts in liquidphase reactions, the additional work could be directed toward the use of different ligands structures with specific requirements for a target reaction. Future applications of the Cr-zeolite catalysts in environmental oxidation reactions should include the oxidation of phenol-containing effluents, as the prepared catalysts demonstrated activity for the reduction of secondary alcohols.

\section{Funding}

B. Silva is thankful for the Project "BioEnv-Biotechnology and Bioengineering for a sustainable world," REF. NORTE-07-0124-FEDER-000048, cofunded by the Programa Operacional Regional do Norte (ON.2 - O Novo Norte), QREN, FEDER. The authors are grateful to FCT and FEDER (European Fund for Regional Development)-COMPETE-QREN-EU for financial support to the Research Centres, PEst-OE/EQB/LA0023/2013, and PEst-C/QUI/UI0686/2013 (F-COMP-01-0124-FEDER-037302).

\section{References}

[1] Wan Ngah, W.S., and Hanafiah, M.A.K.M. (2008). Removal of heavy metal ions from wastewater by chemically modified plant wastes as adsorbents: A review. Bioresour. Technol., 99, 3935-3948.

[2] Bailey, S.E., Olin, T.J., Bricka, R.M., and Adrian, D.D. (1999). A review of potentially lowcost sorbents for heavy metals. Water Res., 33, 2469-2479.

[3] Gavrilescu, M. (2004). Removal of heavy metals from the environment by biosorption. Eng. Life Sci., 4, 219-232.

[4] Agrawal, A., Kumar, V., and Pandey, B.D. (2006). Remediation options for the treatment of electroplating and leather tanning effluent containing chromium - a review. Miner. Process. Extr. Metall. Rev., 27, 99-130.

[5] Le Cloirec, P., Andrè, Y., Faur-Brasquet, C., and Gérente, C. (2003). Engineered biofilms for metal ion removal. Rev. Environ. Sci. Biotechnol., 2, 177-192.

[6] Agarwal, G.S., Bhuptawat, H.K., and Chaudhari, S. (2006). Biosorption of aqueous chromium(VI) by Tamarindus indica seeds. Bioresour. Technol., 97, 949-956.

[7] Dixit, S., Yadav, A., Dwivedi, P.D., and Das, M. (2015). Toxic hazards of leather industry and technologies to combat threat: a review. J. Clean. Prod., 87, 39-49.

[8] Ghiaci, M., Kia, R., Abbaspur, A., and Seyedeyn-Azad, F. (2004). Adsorption of chromate by surfactant-modified zeolites and MCM-41 molecular sieve. Sep. Purif. Technol., 40, 285-295.

[9] Kratochvil, D., and Volesky, B. (1998). Advances in the biosorption of heavy metals. Trends Biotechnol., 16, 291-300.

[10] Yargıç, A.Ş., Yarbay Şahin, R.Z., Özbay, N., and Önal, E. (2015). Assessment of toxic copper(II) biosorption from aqueous solution by chemically-treated tomato waste. J. Clean. Prod., 88, 152-159.

[11] Cheung, K.H., and Gu, J.-D. (2003). Reduction of chromate $\left(\mathrm{CrO}_{4}{ }^{2-}\right)$ by an enrichment consortium and an isolate of marine sulfate-reducing bacteria. Chemosphere, 52, 15231529. 
[12] Cheung, K.H., and Gu, J.-D. (2007). Mechanism of hexavalent chromium detoxification by microorganisms and bioremediation application potential: A review. Int. Biodeterior. Biodegrad., 59, 8-15.

[13] Dermou, E., Velissariou, A., Xenos, D., and Vayenas, D.V. (2005). Biological chromium (VI) reduction using a trickling filter. J. Hazard. Mater., 126, 78-85.

[14] Figueiredo, H., Silva, B., Quintelas, C., Neves, I.C., and Tavares, T. (2010). Effect of the supporting zeolite structure on Cr biosorption: Performance of a single-step reactor and of a sequential batch reactor-A comparison study. Chem. Eng. J., 163, 22-27.

[15] Guha, H., Jayachandran, K., and Maurrasse, F. (2003). Microbiological reduction of chromium(VI) in presence of pyrolusite-coated sand by Shewanella alga Simidu ATCC 55627 in laboratory column experiments. Chemosphere, 52, 175-183.

[16] Kalabegishvili, T.L., Tsibakhashvili, N.Y., and Holman, H.-Y.N. (2003). Electron spin resonance study of chromium(V) formation and decomposition by basalt-inhabiting bacteria. Environ. Sci. Technol., 37, 4678-4684.

[17] Kang, S.-Y., Lee, J.-U., and Kim, K.-W. (2007). Biosorption of $\mathrm{Cr}(\mathrm{III})$ and $\mathrm{Cr}$ (VI) onto the cell surface of Pseudomonas aeruginosa. Biochem. Eng. J., 36, 54-58.

[18] Silva, B., Figueiredo, H., Quintelas, C., Neves, I.C., and Tavares, T. (2008). Zeolites as supports for the biorecovery of hexavalent and trivalent chromium. Microporous Mesoporous Mater., 116, 555-560.

[19] Silva, B., Figueiredo, H., Quintelas, C., Neves, I.C., and Tavares, T. (2012). Improved biosorption for $\mathrm{Cr}(\mathrm{VI})$ reduction and removal by Arthrobacter viscosus using zeolite. Int. Biodeterior. Biodegrad., 74, 116-123.

[20] Babel, S., and Kurniawan, T.A. (2003). Low-cost adsorbents for heavy metals uptake from contaminated water: a review. J. Hazard. Mater., 97, 219-243.

[21] Hernandez-Ramirez, O., and Holmes, S.M. (2008). Novel and modified materials for wastewater treatment applications. J. Mater. Chem., 18, 2751-2761.

[22] Jovanovic, M., Rajic, N., and Obradovic, B. (2012). Novel kinetic model of the removal of divalent heavy metal ions from aqueous solutions by natural clinoptilolite. J. Hazard. Mater., 233-234, 57-64.

[23] Pepe, F., de Gennaro, B., Aprea, P., and Caputo, D. (2013). Natural zeolites for heavy metals removal from aqueous solutions: Modeling of the fixed bed $\mathrm{Ba}^{2+} / \mathrm{Na}^{+}$ ion-exchange process using a mixed phillipsite/chabazite-rich tuff. Chem. Eng. J., $219,37-42$.

[24] Corma, A., and Martínez, A. (2005). Zeolites in refining and petrochemistry. In J. Čejka, and H.v. Bekkum (Eds.), Zeolites and Ordered Mesoporous Materials: Progress and Prospects (pp. 337-366). Netherlands: Elsevier.

[25] Rabo, J.A., and Schoonover, M.W. (2001). Early discoveries in zeolite chemistry and catalysis at Union Carbide, and follow-up in industrial catalysis. Appl. Catal. A., 222, 261-275.

[26] Stöcker, M. (2005). Gas phase catalysis by zeolites. Microporous Mesoporous Mater., 82, 257-292.

[27] Beauchet, R., Mijoin, J., and Magnoux, P. (2009). Improved catalytic oxidation of cumene by formation of catalytically active species during reaction over $\mathrm{NaX}$ zeolite. Appl. Catal. $B, 88,106-112$.

[28] Taralunga, M., Mijoin, J., and Magnoux, P. (2006). Catalytic destruction of 1,2-dichlorobenzene over zeolites. Catal. Commun., 7, 115-121.

[29] Tsou, J., Magnoux, P., Guisnet, M., Órfão, J.J.M., and Figueiredo, J.L. (2003). Oscillations in the oxidation of MIBK over a Pt/HFAU catalyst: role of coke combustion. Catal. Commun., 4, 651-656. 
[30] Tsou, J., Magnoux, P., Guisnet, M., Órfão, J.J.M., and Figueiredo, J.L. (2004). Catalytic oxidation of methyl-isobutyl-ketone over basic zeolites. Appl. Catal. B., 51, 129-133.

[31] von Willingh, G., Abbo, H.S., and Titinchi, S.J.J. (2014). Selective oxidation reactions over tri- and tetradentate oxovanadium(IV) complexes encapsulated in zeolite-Y. Catal. Today, 227, 96-104.

[32] Tidahy, H.L., Siffert, S., Wyrwalski, F., Lamonier, J.F., and Aboukaïs, A. (2007). Catalytic activity of copper and palladium based catalysts for toluene total oxidation. Catal. Today, $119,317-320$.

[33] Wong, C.T., Abdullah, A.Z., and Bhatia, S. (2008). Catalytic oxidation of butyl acetate over silver-loaded zeolites. J. Hazard. Mater., 157, 480-489.

[34] Treesukol, P., Srisuk, K., Limtrakul, J., and Truong, T.N. (2005). Nature of the metal-support interaction in bifunctional catalytic Pt/H-ZSM-5 Zeolite. J. Phys. Chem. B, 109, 11940-11945.

[35] López-Fonseca, R., Gutiérrez-Ortiz, J.I., Gutiérrez-Ortiz, M.A., and González-Velasco, J. R. (2003). Catalytic combustion of chlorinated ethylenes over H-zeolites. J. Chem. Technol. Biotechnol., 78, 15-22.

[36] Spivey, J.J., and Butt, J.B. (1992). Literature review: deactivation of catalysts in the oxidation of volatile organic compounds. Catal. Today, 11, 465-500.

[37] Gaur, V., Sharma, A., and Verma, N. (2005). Catalytic oxidation of toluene and m-xylene by activated carbon fiber impregnated with transition metals. Carbon, 43, 3041-3053.

[38] Lu, C.-Y., and Wey, M.-Y. (2007). Simultaneous removal of VOC and NO by activated carbon impregnated with transition metal catalysts in combustion flue gas. Fuel Process. Technol., 88, 557-567.

[39] Asedegbega-Nieto, E., Díaz, E., Vega, A., and Ordóñez, S. (2010). Transition metalexchanged LTA zeolites as novel catalysts for methane combustion. Catal. Today, 157, 425-431.

[40] Díaz, E., Ordóñez, S., Vega, A., and Coca, J. (2005). Catalytic combustion of hexane over transition metal modified zeolites $\mathrm{NaX}$ and CaA. Appl. Catal. B., 56, 313-322.

[41] Figueiredo, H., Neves, I.C., Quintelas, C., Tavares, T., Taralunga, M., Mijoin, J., and Magnoux, P. (2006). Oxidation catalysts prepared from biosorbents supported on zeolites. Appl. Catal. B, 66, 274-280.

[42] Figueiredo, H., Silva, B., Quintelas, C., Raposo, M.M.M., Parpot, P., Fonseca, A.M., Lewandowska, A.E., Bañares, M.A., Neves, I.C., and Tavares, T. (2010). Immobilization of chromium complexes in zeolite $\mathrm{Y}$ obtained from biosorbents: Synthesis, characterization and catalytic behaviour. Appl. Catal. B., 94, 1-7.

[43] Ribeiro, M.F., Silva, J.M., Brimaud, S., Antunes, A.P., Silva, E.R., Fernandes, A., Magnoux, P., and Murphy, D.M. (2007). Improvement of toluene catalytic combustion by addition of cesium in copper exchanged zeolites. Appl. Catal. B, 70, 384-392.

[44] Silva, B., Figueiredo, H., Santos, V.P., Pereira, M.F.R., Figueiredo, J.L., Lewandowska, A. E., Bañares, M.A., Neves, I.C., and Tavares, T. (2011). Reutilization of Cr-Y zeolite obtained by biosorption in the catalytic oxidation of volatile organic compounds. J. Hazard. Mater., 192, 545-553.

[45] Silva, B., Figueiredo, H., Soares, O.S.G.P., Pereira, M.F.R., Figueiredo, J.L., Lewandowska, A.E., Bañares, M.A., Neves, I.C., and Tavares, T. (2012). Evaluation of ion exchangemodified Y and ZSM5 zeolites in Cr(VI) biosorption and catalytic oxidation of ethyl acetate. Appl. Catal. B, 117-118, 406-413.

[46] Yang, P., Xue, X., Meng, Z., and Zhou, R. (2013). Enhanced catalytic activity and stability of Ce doping on Cr supported HZSM-5 catalysts for deep oxidation of chlorinated volatile organic compounds. Chem. Eng. J., 234, 203-210. 
[47] Clerici, M.G., and Kholdeeva, O.A. (2013). Liquid phase oxidation via heterogeneous catalysis: organic synthesis and industrial applications. Hoboken, New Jersey: John Wiley \& Sons, Inc.

[48] Chisem, I.C., Rafelt, J., Chisem, J., Clark, J.H., Macquarrie, D., Tantoh Shieh, M., Jachuck, R., Ramshaw, C., and Scott, K. (1998). Catalytic oxidation of alkyl aromatics using a novel silica supported Schiff base complex. Chem. Commun., 1949-1950, 1.

[49] Spinacé, E.V., Schuchardt, U., and Cardoso, D. (1999). Oxidation of hydrocarbons with peroxides catalyzed by chromium(III) and iron(III) incorporated in SAPO-37 framework. Appl. Catal. A, 185, L193-L197.

[50] Corma, A., and Garcia, H. (2004). Supramolecular host-guest systems in zeolites prepared by ship-in-a-bottle synthesis. Eur. J. Inorg. Chem., 2004, 1143-1164.

[51] De Vos, D.E., Dams, M., Sels, B.F., and Jacobs, P.A. (2002). Ordered mesoporous and microporous molecular sieves functionalized with transition metal complexes as catalysts for selective organic transformations. Chem. Rev., 102, 3615-3640.

[52] Song, C.E., and S.-g. Lee. (2002). Supported chiral catalysts on inorganic materials. Chem. Rev., 102, 3495-3524.

[53] Wright, J. (2003). Heavy metals and pollution of the lithosphere. New York: Taylor and Francis.

[54] Vijayaraghavan, K., and Yun, Y.-S. (2008). Bacterial biosorbents and biosorption. Biotechnol. Adv., 26, 266-291.

[55] Volesky, B. (1994). Advances in biosorption of metals: Selection of biomass types. FEMS Microbiol. Rev., 14, 291-302.

[56] Mohapatra, S., Hussain, F., and Selvam, P. (2003). Synthesis, characterization, and catalytic properties of chromium-containing hexagonal mesoporous aluminophosphate molecular sieves. Catal. Lett., 85, 217-222.

[57] Park, D., Yun, Y.-S., Ahn, C.K., and Park, J.M. (2007). Kinetics of the reduction of hexavalent chromium with the brown seaweed Ecklonia biomass. Chemosphere, 66, 939-946.

[58] Mohan, D., and Pittman Jr, C.U. (2006). Activated carbons and low cost adsorbents for remediation of tri- and hexavalent chromium from water. J. Hazard. Mater., 137, 762811.

[59] Takeno, N. (2005). Atlas of Eh-pH diagrams. Intercomparison of thermodynamic databases, Open File Report No. 419, in, National Institute of Advanced Industrial Science and Technology, Geological Survey of Japan, Tokyo, Japan, 2005.

[60] Fendorf, S.E., and Li, G. (1996). Kinetics of chromate reduction by ferrous iron. Environ. Sci. Technol., 30, 1614-1617.

[61] Kotaś, J., and Stasicka, Z. (2000). Chromium occurrence in the environment and methods of its speciation. Environ. Pollut., 107, 263-283.

[62] Palmer, C.D., and Puls, R.W. (1994). Natural attenuation of hexavalent chromium in ground water and soils, in: EPA/540/5-94/505.

[63] Hawley, E.L., Deeb, R.A., Kavanaugh, M.C., and Jacobs, J.A. (2005). Treatment technologies for chromium(VI). In J. Guertin, J.A. Jacobs, and C.P. Avakian (Eds.), Chromium (VI) Handbook (pp. 275-309). Florida: CRC Press.

[64] Cervantes, C., Campos-García, J., Devars, S., Gutiérrez-Corona, F., Loza-Tavera, H., Torres-Guzmán, J.C., and Moreno-Sánchez, R. (2001). Interactions of chromium with microorganisms and plants. FEMS Microbiol. Rev., 25, 335-347.

[65] Desai, C., Jain, K., and Madamwar, D. (2008). Hexavalent chromate reductase activity in cytosolic fractions of Pseudomonas sp. G1DM21 isolated from $\mathrm{Cr}(\mathrm{VI})$ contaminated industrial landfill. Process Biochem., 43, 713-721.

[66] Liu, Y.-G., Xu, W.-H., Zeng, G.-M., Li, X., and Gao, H. (2006). Cr(VI) reduction by Bacillus sp. isolated from chromium landfill. Process Biochem., 41, 1981-1986. 
[67] Zhu, W., Chai, L., Ma, Z., Wang, Y., Xiao, H., and Zhao, K. (2008). Anaerobic reduction of hexavalent chromium by bacterial cells of Achromobacter sp. Strain Ch1. Microbiol. Res., 163, 616-623.

[68] Lin, Y.-H., Wu, C.-L., Li, H.-L., and Hsu, C.-H. (2011). Verification of model for adsorption and reduction of chromium(VI) by Escherichia coli 33456 using chitosan bead as a supporting medium. Appl. Math. Model., 35, 2736-2751.

[69] Rege, M., Petersen, J., Johnstone, D., Turick, C., Yonge, D., and Apel, W. (1997). Bacterial reduction of hexavalent chromium by Enterobacter cloacae strain $\mathrm{HO}$ grown on sucrose. Biotechnol. Lett., 19, 691-694.

[70] Namasivayam, C., and Sureshkumar, M.V. (2008). Removal of chromium(VI) from water and wastewater using surfactant modified coconut coir pith as a biosorbent. Bioresour. Technol., 99, 2218-2225.

[71] Duffus, J.H. (2005). Chemical speciation terminology: chromium chemistry and cancer. Mineral. Mag., 69, 557-562.

[72] Chandra Babu, N.K., Asma, K., Raghupathi, A., Venba, R., Ramesh, R., and Sadulla, S. (2005). Screening of leather auxiliaries for their role in toxic hexavalent chromium formation in leather-posing potential health hazards to the users. J. Clean. Prod., 13, $1189-1195$.

[73] Cefalu, W.T., and Hu, F.B. (2004). Role of chromium in human health and in diabetes. Diabetes Care, 27, 2741-2751.

[74] Sharma, S., and Adholeya, A. (2011). Detoxification and accumulation of chromium from tannery effluent and spent chrome effluent by Paecilomyces lilacinus fungi. Int. Biodeterior. Biodegrad., 65, 309-317.

[75] Nickens, K.P., Patierno, S.R., and Ceryak, S. (2010). Chromium genotoxicity: A doubleedged sword. Chem. Biol. Interact., 188, 276-288.

[76] Wang, J., and Chen, C. (2006). Biosorption of heavy metals by Saccharomyces cerevisiae: A review. Biotechnol. Adv., 24, 427-451.

[77] Arief, V.O., Trilestari, K., Sunarso, J., Indraswati, N., and Ismadji, S. (2008). Recent progress on biosorption of heavy metals from liquids using low cost biosorbents: characterization, biosorption parameters and mechanism studies. Clean, 36, 937-962.

[78] Brady, D., Stoll, A., and Duncan, J.R. (1994). Biosorption of heavy metal cations by non- viable yeast biomass. Environ. Technol., 15, 429-438.

[79] Garnham, G.W. (1997). Biosorbents for metal ions. London: Taylor and Francis Ltd.

[80] Volesky, B. (1990). Removal and recovery of heavy metals by biosorption. In B. Volesky (Ed.), Biosorption of Heavy Metals (pp. 7-43). Boca Raton, Florida: CRC Press.

[81] Veglio, F., and Beolchini, F. (1997). Removal of metals by biosorption: a review. Hydrometallurgy, 44, 301-316.

[82] Volesky, B., and Schiewer, S. (2000). Biosorption, metals. In: M.C. Flickinger, S.W. Drew (Eds.), Encyclopedia of Bioprocess Technology - Fermentation, Biocatalysis and Bioseparation (pp. 53-433). USA: John Wiley \& Sons.

[83] Kulczycki, E., Ferris, F.G., and Fortin, D. (2002). Impact of cell wall structure on the behavior of bacterial cells as sorbents of cadmium and lead. Geomicrobiol. J., 19, 553-565.

[84] Park, D., Yun, Y.-S., and Park, J. (2010). The past, present, and future trends of biosorption. Biotechnol. Bioproc. E., 15, 86-102.

[85] López, E., Ramos, I., and Sanromán, M.A. (2003). Extracellular polysaccharides production by Arthrobacter viscosus. J. Food Eng., 60, 463-467.

[86] Crocker, F.H., Fredrickson, J.K., White, D.C., Ringelberg, D.B., and Balkwill, D.L. (2000). Phylogenetic and physiological diversity of Arthrobacter strains isolated from unconsolidated subsurface sediments. Microbiology, 146, 1295-1310. 
[87] Westerberg, K., Elväng, A.M., Stackebrandt, E., and Jansson, J.K. (2000). Arthrobacter chlorophenolicus sp. nov., a new species capable of degrading high concentrations of 4chlorophenol. Int. J. Syst. Evol. Microbiol., 50, 2083-2092.

[88] O’Loughlin, E., Sims, G., and Traina, S. (1999). Biodegradation of 2-methyl, 2-ethyl, and 2-hydroxypyridine by an Arthrobacter sp. isolated from subsurface sediment. Biodegradation, 10, 93-104.

[89] Novak, J.S., Tanenbaum, S.W., and Nakas, J.P. (1992). Heteropolysaccharide formation by Arthrobacter viscosus grown on xylose and xylose oligosaccharides. Appl. Environ. Microbiol., 58, 3501-3507.

[90] Scott, J.A., and Palmer, S.J. (1988). Cadmium biosorption by bacterial exopolysaccharide. Biotechnol. Lett., 10, 21-24.

[91] Sloneker, J.H., Orentas, D.G., Knutson, C.A., Watson, P.R., and Jeanes, A. (1968). Structure of the extracellular bacterial polysaccharide from Arthrobacter viscosus NRRL B1973. Can. J. Chem., 46, 3353-3361.

[92] Guibaud, G., van Hullebusch, E., and Bordas, F. (2006). Lead and cadmium biosorption by extracellular polymeric substances (EPS) extracted from activated sludges: $\mathrm{pH}$-sorption edge tests and mathematical equilibrium modelling. Chemosphere, 64, 1955-1962.

[93] Quintelas, C., Fonseca, B., Silva, B., Figueiredo, H., and Tavares, T. (2009). Treatment of chromium(VI) solutions in a pilot-scale bioreactor through a biofilm of Arthrobacter viscosus supported on GAC. Bioresour. Technol., 100, 220-226.

[94] Pagnanelli, F., Petrangeli Papini, M., Trifoni, M., and Vegliò, F. (2000). Biosorption of metal ions on arthrobacter sp.: biomass characterization and biosorption modeling. Environ. Sci. Technol., 34, 2773-2778.

[95] Veglió, F., Beolchini, F., and Gasbarro, A. (1997). Biosorption of toxic metals: an equilibrium study using free cells of Arthrobacter sp. Process Biochem., 32, 99-105.

[96] Lin, Z., Zhu, Y., Kalabegishvili, T.L., Tsibakhashvili, N.Y., and Holman, H.-Y. (2006). Effect of chromate action on morphology of basalt-inhabiting bacteria. Mater. Sci. Eng., C, 26, 610-612.

[97] Tsibakhashvili, N.Y., Mosulishvili, L.M., Kalabegishvili, T.L., Kirkesali, E.I., Frontasyeva, M.V., Pomyakushina, E.V., Pavlov, S.S., and Holman, H.Y.N. (2004). ENAA studies of chromium uptake by Arthrobacter oxydans. J. Radioanal. Nucl. Chem., 259, 527-531.

[98] Lytle, C.M., Lytle, F.W., Yang, N., Qian, J.-H., Hansen, D., Zayed, A., and Terry, N. (1998). Reduction of $\mathrm{Cr}(\mathrm{VI})$ to $\mathrm{Cr}(\mathrm{III})$ by Wetland Plants: Potential for in situ heavy metal detoxification. Environ. Sci. Technol., 32, 3087-3093.

[99] Gardea-Torresdey, J.L., Tiemann, K.J., Armendariz, V., Bess-Oberto, L., Chianelli, R.R., Rios, J., Parsons, J.G., and Gamez, G. (2000). Characterization of $\mathrm{Cr}(\mathrm{VI})$ binding and reduction to $\mathrm{Cr}$ (III) by the agricultural byproducts of Avena monida (Oat) biomass. J. Hazard. Mater., 80, 175-188.

[100] Park, D., Yun, Y.-S., and Park, J.M. (2004). Reduction of hexavalent chromium with the brown seaweed ecklonia biomass. Environ. Sci. Technol., 38, 4860-4864.

[101] Park, D., Yun, Y.-S., Hye Jo, J., and Park, J.M. (2005). Mechanism of hexavalent chromium removal by dead fungal biomass of Aspergillus niger. Water Res., 39, 533-540.

[102] Park, D., Yun, Y.-S., Kim, J.Y., and Park, J.M. (2008). How to study Cr(VI) biosorption: Use of fermentation waste for detoxifying $\mathrm{Cr}(\mathrm{VI})$ in aqueous solution. Chem. Eng. J., 136, 173-179.

[103] Cui, H., Fu, M., Yu, S., and Wang, M.K. (2011). Reduction and removal of Cr(VI) from aqueous solutions using modified byproducts of beer production. J. Hazard. Mater., 186, $1625-1631$.

[104] Deng, L., Zhang, Y., Qin, J., Wang, X., and Zhu, X. (2009). Biosorption of Cr(VI) from aqueous solutions by nonliving green algae Cladophora albida. Miner. Eng., 22, 372-377. 
[105] Janoš, P., Hůla, V., Bradnová, P., Pilařová, V., and Šedlbauer, J. (2009). Reduction and immobilization of hexavalent chromium with coal- and humate-based sorbents. Chemosphere, 75, 732-738.

[106] Murphy, V., Tofail, S.A.M., Hughes, H., and McLoughlin, P. (2009). A novel study of hexavalent chromium detoxification by selected seaweed species using SEM-EDX and XPS analysis. Chem. Eng. J., 148, 425-433.

[107] Wu, J., Zhang, H., He, P.-J., Yao, Q., and Shao, L.-M. (2010). Cr(VI) removal from aqueous solution by dried activated sludge biomass. J. Hazard. Mater., 176, 697-703.

[108] Payra, P., and Dutta, P.K. (2003). Zeolites: A primer. In S.M. Auerbach, K.A. Carrado, and P.K. Dutta (Eds.), Handbook of Zeolite Science and Technology (pp. 1-23). New York: CRC Press.

[109] Flanigen, E.M. (2001). Zeolites and molecular sieves: An historical perspective. In H.v. Bekkum, E.M. Flanigen, P.A. Jacobs, and J.C. Jansen (Eds.), Introduction to Zeolite Science and Practice (pp. 11-35). Netherlands: Elsevier.

[110] Guisnet, M., and Gilson, J.-P. (2002). Introduction to zeolite science and technology. In M. Guisnet, and J.-P. Gilson (Eds.), Zeolites for Cleaner Technologies (pp. 1-28). London: Imperial College Press.

[111] Lobo, R.F. (2003). Introduction to the structural chemistry of zeolites. In S.M. Auerbach, K.A. Carrado, and P.K. Dutta (Eds.), Handbook of Zeolite Science and Technology (pp. 80-113). New York: CRC Press.

[112] Loganathan, P., Vigneswaran, S., Kandasamy, J., and Naidu, R. (2013). Defluoridation of drinking water using adsorption processes. J. Hazard. Mater., 248-249, 1-19.

[113] Jodaei, A., Salari, D., Niaei, A., Khatamian, M., and Hosseini, S.A. (2010). Oxidation of ethyl acetate by a high performance nanostructure ( $\mathrm{Ni}, \mathrm{Mn})-\mathrm{Ag} / \mathrm{ZSM}-5$ bimetallic catalysts and development of an artificial neural networks predictive modeling. J. Environ. Sci. Health., Part A, 46, 50-62.

[114] Erdem, E., Karapinar, N., and Donat, R. (2004). The removal of heavy metal cations by natural zeolites. J. Colloid Interface Sci., 280, 309-314.

[115] Vaca Mier, M., López Callejas, R., Gehr, R., Jiménez Cisneros, B.E., and Alvarez, P.J.J. (2001). Heavy metal removal with mexican clinoptilolite:: multi-component ionic exchange. Water Res., 35, 373-378.

[116] Chelishchev, N.F. (1993). Use of natural zeolites at Chernobyl. In D.W. Mumpton, and F. A. Ming (Eds.), Natural Zeolites '93 (pp. 525-532). New York: International Committee on Natural Zeolites.

[117] Colella, C. (2007). Recent advances in natural zeolite applications based on external surface interaction with cations and molecules. In R. Xu, Z. Gao, J. Chen, and W. Yan (Eds.), Studies in Surface Science and Catalysis (pp. 2063-2073). Elsevier.

[118] Solache-Ríos, M. Cation-exchange capacities of zeolites A, X, Y, ZSM-5 and Mexican erionite compared with the retention of cobalt and cadmium. J. Radioanal. Nucl. Chem., 250, 205-206.

[119] Inglezakis, V.J., Loizidou, M.D., and Grigoropoulou, H.P. (2003). Ion exchange of $\mathrm{Pb}^{2+}$, $\mathrm{Cu}^{2+}, \mathrm{Fe}^{3+}$, and $\mathrm{Cr}^{3+}$ on natural clinoptilolite: selectivity determination and influence of acidity on metal uptake. J. Colloid Interface Sci., 261, 49-54.

[120] Kesraoui-Ouki, S., Cheeseman, C.R., and Perry, R. (1994). Natural zeolite utilisation in pollution control: A review of applications to metals' effluents. J. Chem. Technol. Biotechnol., 59, 121-126.

[121] Kocaoba, S., Orhan, Y., and Akyüz, T. (2007). Kinetics and equilibrium studies of heavy metal ions removal by use of natural zeolite. Desalination, 214, 1-10. 
[122] Perić, J., Trgo, M., and Vukojević Medvidović, N. (2004). Removal of zinc, copper and lead by natural zeolite-a comparison of adsorption isotherms. Water Res., 38, 18931899.

[123] Basaldella, E.I., Vázquez, P.G., Iucolano, F., and Caputo, D. (2007). Chromium removal from water using LTA zeolites: Effect of pH. J. Colloid Interface Sci., 313, 574-578.

[124] Biškup, B., and Subotić, B. (2004). Kinetic analysis of the exchange processes between sodium ions from zeolite A and cadmium, copper and nickel ions from solutions. Sep. Purif. Technol., 37, 17-31.

[125] Gazola, F.C., Pereira, M.R., Barros, M.A.S.D., Silva, E.A., and Arroyo, P.A. (2006). Removal of $\mathrm{Cr}^{3+}$ in fixed bed using zeolite NaY. Chem. Eng. J., 117, 253-261.

[126] Ostroski, I.C., Barros, M.A.S.D., Silva, E.A., Dantas, J.H., Arroyo, P.A., and Lima, O.C.M. (2009). A comparative study for the ion exchange of Fe(III) and $\mathrm{Zn}$ (II) on zeolite NaY. J. Hazard. Mater., 161, 1404-1412.

[127] Leyva-Ramos, R., Jacobo-Azuara, A., Diaz-Flores, P.E., Guerrero-Coronado, R.M., Mendoza-Barron, J., and Berber-Mendoza, M.S. (2008). Adsorption of chromium(VI) from an aqueous solution on a surfactant-modified zeolite. Colloids Surf., A, 330, 35-41.

[128] Yusof, A.M., and Malek, N.A.N.N. (2009). Removal of $\mathrm{Cr}(\mathrm{VI})$ and $\mathrm{As}(\mathrm{V})$ from aqueous solutions by HDTMA-modified zeolite Y. J. Hazard. Mater., 162, 1019-1024.

[129] Deng, S., and Bai, R. (2004). Removal of trivalent and hexavalent chromium with aminated polyacrylonitrile fibers: performance and mechanisms. Water Res., 38, 2424-2432.

[130] Jain, M., Garg, V.K., and Kadirvelu, K. (2009). Equilibrium and kinetic studies for sequestration of $\mathrm{Cr}(\mathrm{VI})$ from simulated wastewater using sunflower waste biomass. $J$. Hazard. Mater., 171, 328-334.

[131] Li, J., Lin, Q., Zhang, X., and Yan, Y. (2009). Kinetic parameters and mechanisms of the batch biosorption of $\mathrm{Cr}(\mathrm{VI})$ and $\mathrm{Cr}(\mathrm{III})$ onto Leersia hexandra Swartz biomass. J. Colloid Interface Sci., 333, 71-77.

[132] Arends, I.W.C.E., and Sheldon, R.A. (2001). Activities and stabilities of heterogeneous catalysts in selective liquid phase oxidations: recent developments. Appl. Catal., A, 212, $175-187$.

[133] McMorn, P., and Hutchings, G.J. (2004). Heterogeneous enantioselective catalysts: strategies for the immobilisation of homogeneous catalysts. Chem. Soc. Rev., 33, 108-122.

[134] Liotta, L.F. (2010). Catalytic oxidation of volatile organic compounds on supported noble metals. Appl. Catal., B, 100, 403-412.

[135] Hunter, P., and Oyama, S.T. (2000). Control of volatile organic compound emissions: conventional and emerging technologies. New Jersey: Jonh Wiley \& Sons, Inc.

[136] Jenkin, M.E., Saunders, S.M., Derwent, R.G., and Pilling, M.J. (2002). Development of a reduced speciated VOC degradation mechanism for use in ozone models. Atmos. Environ., 36, 4725-4734.

[137] Derwent, R.G. (1995). Sources, distributions and fates of VOCs in the atmosphere. In R. E. Hester, and R.M. Harrison (Eds.), Volatile Organic Compounds in the Atmosphere (pp. 1-16). Cambridge: The Royal Society of Chemistry.

[138] Khan, F.I., and Ghoshal, A. Kr. (2000). Removal of volatile organic compounds from polluted air. J. Loss Prevent. Proc., 13, 527-545.

[139] Everaert, K., and Baeyens, J. (2004). Catalytic combustion of volatile organic compounds. J. Hazard. Mater., 109, 113-139.

[140] Kim, S.C., and Shim, W.G. (2008). Complete oxidation of volatile organic compounds over $\mathrm{Ce} / \mathrm{Cu} /$ gamma- $\mathrm{Al}_{2} \mathrm{O}_{3}$ catalyst. Environ. Technol., 29, 535-542.

[141] Noordally, E., Richmond, J.R., and Drumm, K.J. (1994). Catalytic oxidation processes for odour and VOC control. In S. Vigneron, J. Hermia, and J. Chaouki (Eds.), Studies 
Characterization and Control of Odours and VOC in the Process Industries (pp. 459-467). Netherlands: Elsevier.

[142] Spivey, J.J. (1987). Complete catalytic oxidation of volatile organics. Ind. Eng. Chem. Res., 26, 2165-2180.

[143] Wang, A., and Jing, H. (2014). Tunable catalytic activities and selectivities of metal ion doped TiO2 nanoparticles - oxidation of organic compounds. Dalton Trans., 43, 10111018.

[144] Yao, Y.-F.Y. (1980). Oxidation of alkanes over noble metal catalysts. Ind. Eng. Chem. Prod. $R D, 19,293-298$.

[145] Hermia, J., and Vigneron, S. (1993). Catalytic incineration for odour abatement and VOC destruction. Catal. Today, 17, 349-358.

[146] Burch, R., Crittle, D.J., and Hayes, M.J. (1999). C-H bond activation in hydrocarbon oxidation on heterogeneous catalysts. Catal. Today, 47, 229-234.

[147] O'Malley, A., and Hodnett, B.K. (1999). The influence of volatile organic compound structure on conditions required for total oxidation. Catal. Today, 54, 31-38.

[148] Avgouropoulos, G., Oikonomopoulos, E., Kanistras, D., and Ioannides, T. (2006). Complete oxidation of ethanol over alkali-promoted Pt/Al2O3 catalysts. Appl. Catal., B, 65, 62-69.

[149] Sawyer, J.E., and Abraham, M.A. (1994). Reaction pathways during the oxidation of ethyl acetate on a platinum/alumina catalyst. Ind. Eng. Chem. Res., 33, 2084-2089.

[150] López-Fonseca, R., Gutiérrez-Ortiz, J.I., Gutiérrez-Ortiz, M.A., and González-Velasco, J. R. (2005). Catalytic oxidation of aliphatic chlorinated volatile organic compounds over Pt/H-BETA zeolite catalyst under dry and humid conditions. Catal. Today, 107-108, 200-207.

[151] Tsou, J., Magnoux, P., Guisnet, M., Órfão, J.J.M., Figueiredo, J.L. (2005). Catalytic oxidation of volatile organic compounds: Oxidation of methyl-isobutyl-ketone over Pt/zeolite catalysts. Appl. Catal., B., 57, 117-123.

[152] Tidahy, H.L., Siffert, S., Lamonier, J.F., Cousin, R., Zhilinskaya, E.A., Aboukaï, A., Su, B. L., Canet, X., De Weireld, G., Frère, M., Giraudon, J.M., and Leclercq, G. (2007). Influence of the exchanged cation in Pd/BEA and Pd/FAU zeolites for catalytic oxidation of VOCs. Appl. Catal., B., 70, 377-383.

[153] Abdullah, A.Z., Bakar, M.Z.A., and Bhatia, S. (2003). Effect of hydrogen treatment on the performance of Cr-ZSM-5 in deep oxidative decomposition of ethyl acetate and benzene in air. Catal. Commun., 4, 555-560.

[154] Antunes, A.P., Ribeiro, M.F., Silva, J.M., Ribeiro, F.R., Magnoux, P., and Guisnet, M. (2001). Catalytic oxidation of toluene over CuNaHY zeolites: Coke formation and removal. Appl. Catal., B., 33, 149-164.

[155] Farzaneh, F., Sadeghi, S., Turkian, L., and Ghandi, M. (1998). The oxidation of alkenes in the presence of some transition metal elements exchanged with zeolites. J. Mol. Catal. A: Chem., 132, 255-261.

[156] Baek, S.-W., Kim, J.-R., Ihm, S.-K. (2004). Design of dual functional adsorbent/catalyst system for the control of VOC's by using metal-loaded hydrophobic Y-zeolites. Catal. Today, 93-95, 575-581.

[157] Guillemot, M., Mijoin, J., Mignard, S., and Magnoux, P. (2007). Volatile organic compounds (VOCs) removal over dual functional adsorbent/catalyst system. Appl. Catal., B., $75,249-255$.

[158] Lounis, Z., Riahi, A., Djafri, F., and Muzart, J. (2006). Chromium-exchanged zeolite (CrE-ZSM-5) as catalyst for alcohol oxidation and benzylic oxidation with $\mathrm{t}-\mathrm{BuOOH}$. Appl. Catal., A., 309, 270-272. 
[159] Jin, C., Fan, W., Jia, Y., Fan, B., Ma, J., and Li, R. (2006). Encapsulation of transition metal tetrahydro-Schiff base complexes in zeolite $\mathrm{Y}$ and their catalytic properties for the oxidation of cycloalkanes. J. Mol. Catal. A: Chem., 249, 23-30.

[160] Kuźniarska-Biernacka, I., Biernacki, K., Magalhães, A.L., Fonseca, A.M., and Neves, I.C. (2011). Catalytic behavior of 1-(2-pyridylazo)-2-naphthol transition metal complexes encapsulated in Y zeolite. J. Catal., 278, 102-110.

[161] Chen, J.D., Lempers, H.E.B., Sheldon, R.A., , F.T.T., Chuiko, A.A., Gun'Ko, V. (1995). Ti-Al- $\beta$ and CrAPO-5 as heterogeneous catalysts for selective oxidations in the liquid phase. Colloids Surf. A, Physicochem. Eng. Aspects, 101, 137-146.

[162] Tarainasso, M., Perego, G., and Notari, B. (1983). US Patent 4410501.

[163] Sheldon, R.A., Wallau, M., Arends, I.W.C.E., and Schuchardt, U. (1998). Heterogeneous catalysts for liquid-phase oxidations: Philosophers' Stones or Trojan Horses? Acc. Chem. Res., 31, 485-493.

[164] Vos, D., Knops-Gerrits, P.P., Parton, R., Weckhuysen, B., Jacobs, P., and Schoonheydt, R. (1995). Coordination chemistry in zeolites. J. Incl. Phenom. Macrocycl. Chem., 21, 185213.

[165] Davis, M.E. (2002). Ordered porous materials for emerging applications. Nature, 417, 813-821.

[166] Grommen, R., Manikandan, P., Gao, Y., Shane, T., Shane, J.J., Schoonheydt, R.A., Weckhuysen, B.M., and Goldfarb, D. (2000). Geometry and framework interactions of zeoliteencapsulated Copper(II)-histidine complexes. J. Am. Chem. Soc., 122, 11488-11496.

[167] Knops-Gerrits, P.-P., De Vos, D., Thibault-Starzyk, F., and Jacobs, P.A. (1994). Zeoliteencapsulated $\mathrm{Mn}$ (II) complexes as catalysts for selective alkene oxidation. Nature, 369, 543-546.

[168] Muzart, J. (1992). Chromium-catalyzed oxidations in organic synthesis. Chem. Rev., 92, 113-140.

[169] Nakamura, H., and Matsuhashi, H. (1995). Heterogeneous liquid-phase oxidation of alcohols with solid oxidizing reagents of vanadium(V) oxide and chromium(VI) oxide supported on zirconium(IV) oxide. Bull. Chem. Soc. Jpn., 68, 997-1000.

[170] Weckhuysen, B.M., Wachs, I.E., Schoonheydt, R.A. (1996). Surface chemistry and spectroscopy of chromium in inorganic oxides. Chem. Rev., 96, 3327-3350.

[171] Cruz, R.S., Souza e Silva, J.M., Arnold, U., and Schuchardt, U. Catalytic activity and stability of a chromium containing silicate in liquid phase cyclohexane oxidation. J. Mol. Catal. A: Chem., 171, 251-257.

[172] Lou, J.D., Zhu, L.H., Pan, L.L., Li, L., Li, F., and Gao, C.L. (2006). Solvent-free oxidation of secondary alcohols with chromium trioxide. Synth. React. Inorg. Met.-Org. NanoMetal Chem., 36, 585-587.

[173] Salavati-Niasari, M., Zamani, E., Ganjali, M.R., and Norouzi, P. (2007). Synthesis, characterization and liquid phase oxidation of cyclohexanol using tert-butylhydroperoxide over host (zeolite-Y)/guest (copper(II) complexes of 12- and 13-membered diaza dioxa Schiffbase macrocyclic ligand) nanocomposite materials (HGNM). J. Mol. Catal. A: Chem., 261, 196-201.

[174] Parentis, M., Bonini, N., and Gonzo, E. (2002). Catalytic reactivity of $\mathrm{Cr} / \mathrm{SiO}_{2}$ in the liquid phase oxidation of cyclohexanol by tert-butyl hydroperoxide. React. Kinet. Catal. Lett., 76, 243-248.

[175] Laha, S.C., and Gläser, R. (2007). Characterization and catalytic performance of [Cr] MCM-41 and [Cr]MCM-48 prepared by either classical or microwave heating. Microporous Mesoporous Mater., 99, 159-166.

[176] Bautista, F.M., Campelo, J.M., Garcia, A., Luna, D., Marinas, J.M., Romero, A.A., and Urbano, M.R. (1994). Chromium-aluminium orthophosphates, III. Acidity and catalytic 
performance in cyclohexene and cumene conversions on $\mathrm{CrPO}_{4}-\mathrm{AlPO}_{4}(20-50$ wt.\% AlPO4) catalysts obtained in aqueous ammonia. React. Kinet. Catal. Lett., 53, 55-63.

[177] Sakthivel, A., Dapurkar, S., and Selvam, P. (2001). Mesoporous (Cr)MCM-41 and (Cr) MCM-48 molecular sieves: promising heterogeneous catalysts for liquid phase oxidation reactions. Catal. Lett., 77, 155-158.

[178] Sakthivel, A., Dapurkar, S.E., and Selvam, P. (2003). Allylic oxidation of cyclohexene over chromium containing mesoporous molecular sieves. Appl. Catal., A., 246, 283-293.

[179] Adam, F., and Fook, C. (2009). Chromium modified silica from rice husk as an oxidative catalyst. J. Porous Mater., 16, 291-298.

[180] Salavati-Niasari, M. (2008). Host (nanopores of zeolite-Y)/guest [manganese(II) with 12membered tetradentate $\mathrm{N}_{2} \mathrm{O}_{2}, \mathrm{~N}_{2} \mathrm{~S}_{2}$ and $\mathrm{N}_{4}$ donor macrocyclic ligands] nanocatalysts: flexible ligand synthesis, characterization and catalytic activity. Trans. Met. Chem., 33, 443-452.

[181] Salavati-Niasari, M., Shaterian, M., Ganjali, M.R., and Norouzi, P. (2007). Oxidation of cyclohexene with tert-butylhydroperoxide catalysed by host (nanocavity of zeolite-Y)/ guest $\left(\mathrm{Mn}(\mathrm{II}), \mathrm{Co}(\mathrm{II}), \mathrm{Ni}(\mathrm{II})\right.$ and $\mathrm{Cu}(\mathrm{II})$ complexes of $\mathrm{N}, \mathrm{N}^{\prime}$-bis(salicylidene)phenylene1,3-diamine) nanocomposite materials (HGNM). J. Mol. Catal. A: Chem., 261, 147-155.

[182] Salavati-Niasari, M., and Abdolmohammadi, S. (2008). Host (nanocavity of zeolite-Y)/ guest (12- and 14-membered azamacrocyclic $\mathrm{Ni}(\mathrm{II})$ complexes) nanocatalyst: synthesis, characterization and catalytic oxidation of cyclohexene with molecular oxygen. J. Inclusion Phenomena Macrocyclic Chem., 60, 145-152.

[183] Abbo, H., and Titinchi, S.J. (2010). Metallo salicylidenetriazol complexes encapsulated in zeolite-Y: synthesis, physicochemical properties and catalytic studies. Top. Catal., 53, 1401-1410.

[184] Salavati-Niasari, M. (2008). Host (nanocage of zeolite-Y)/guest (manganese(II), cobalt (II), nickel(II) and copper(II) complexes of 12-membered macrocyclic Schiff-base ligand derived from thiosemicarbazide and glyoxal) nanocomposite materials: Synthesis, characterization and catalytic oxidation of cyclohexene. J. Mol. Catal. A: Chem., 283, 120-128.

[185] Salavati-Niasari, M., and Babazadeh-Arani, H. (2007). Cyclohexene oxidation with tertbutylhydroperoxide and hydrogen peroxide catalyzed by new square-planar manganese (II), cobalt(II), nickel(II) and copper(II) bis(2-mercaptoanil)benzil complexes supported on alumina. J. Mol. Catal. A: Chem., 274, 58-64.

[186] Pirngruber, G.D., Frunz, L., and Luchinger, M. (2009). The characterisation and catalytic properties of biomimetic metal-peptide complexes immobilised on mesoporous silica. Phys. Chem. Chem. Phys., 11, 2928-2938.

[187] Nunes, N., Amaro, R., Costa, F., Rombi, E., Carvalho, M.A., Neves, I.C., and Fonseca, A.M. (2007). Copper(II)-purine complexes encapsulated in NaY zeolite. Eur. J. Inorg. Chem., 2007, 1682-1689.

[188] Nowak, I., Kilos, B., Ziolek, M., and Lewandowska, A. (2003). Epoxidation of cyclohexene on Nb-containing meso- and macroporous materials. Catal. Today, 78, 487-498.

[189] Kanmani, A.S., and Vancheesan, S. (1999). Selective oxidation of alkenes catalysed by ruthenium(II) complexes containing coordinated perchlorate. J. Mol. Catal. A: Chem., $150,95-104$. 